LA-14441

Approved for public release;

distribution is unlimited.

\title{
2010 LANL Radionuclide Air Emissions Report
}


Funding for this report was provided by the U.S. Department of Energy.

Edited by Hector Hinojosa of Group IRM-CAS.

Los Alamos National Laboratory, an Affirmative Action/ Equal Opportunity Employer, is operated by Los Alamos National Security, LLC, for the National Nuclear Security Administration of the U.S. Department of Energy under contract DE-AC52-06NA25396.

This report was prepared as an account of work sponsored by an agency of the U.S. Government. Neither Los Alamos National Security, LLC, the U.S. Government nor any agency thereof, nor any of their employees make any warranty, express or implied, or assume any legal liability or responsibility for the accuracy, completeness, or usefulness of any information, apparatus, product, or process disclosed, or represent that its use would not infringe privately owned rights. Reference herein to any specific commercial product, process, or service by trade name, trademark, manufacturer, or otherwise does not necessarily constitute or imply its endorsement, recommendation, or favoring by Los Alamos National Security, LLC, the U.S. Government, or any agency thereof. The views and opinions of authors expressed herein do not necessarily state or reflect those of Los Alamos National Security, LLC, the U.S. Government, or any agency thereof. Los Alamos National Laboratory strongly supports academic freedom and a researcher's right to publish; as an institution, however, the Laboratory does not endorse the viewpoint of a publication or guarantee its technical correctness. 
LA-14441

Issued: June 2011

2010 LANL Radionuclide Air Emissions Report

David P. Fuehne 



\section{U. S. Department of Energy Report}

\section{LANL Radionuclide Air Emissions}

Site Name: Los Alamos National Laboratory

Location: County of Los Alamos, New Mexico

\section{Operations Office Information:}

Office: $\quad$ Los Alamos Site Office

Address: $\quad$ U.S. Department of Energy

National Nuclear Security Administration

Los Alamos Site Office

3747 West Jemez Road

Los Alamos, NM 87544

Contact: Hai Shen $\quad$ Phone: (505) 665-5046

Site Information:

Operator: Los Alamos National Security, LLC

Address: $\quad$ Los Alamos National Laboratory

PO Box 1663

Los Alamos, NM 87545

Contact: David Fuehne Phone: (505) 665-3850

\section{Compliance Assessment:}

2010 Off-Site Effective Dose Equivalent: $\quad 0.33$ mrem 



\section{LANL Radionuclide Air Emissions Report}

\section{Executive Summary}

This report describes the reported dose from emissions of radionuclides at Los Alamos National Laboratory (LANL) for calendar year 2010. This report fulfills the requirements established by the National Emissions Standards for Hazardous Air Pollutants - Emissions of Radionuclides other than Radon from Department of Energy Facilities (Radionuclide NESHAP or Rad-NESHAP). This report is prepared by LANL's Rad-NESHAP compliance team, which is part of the Environmental Protection Division. The information in this report is required under the Clean Air Act and is being reported to the U.S. Environmental Protection Agency (EPA). The highest effective dose equivalent (EDE) to an off-site member of the public was calculated using procedures specified by the EPA and described in this report. LANL's EDE was 0.33 mrem for 2010. The annual limit established by the EPA is 10 mrem per year. All emissions are modeled to this single location, dubbed the Maximally Exposed Individual (MEI).

During calendar year 2010, LANL continuously monitored radionuclide emissions at 28 "major" release points, or stacks. The Laboratory estimates emissions from an additional 31 "minor” release points using radionuclide usage source terms in lieu of stack monitoring. Also, LANL uses a network of air samplers around the Laboratory perimeter to monitor ambient airborne levels of radionuclides. To provide data for dispersion modeling and dose assessment, LANL maintains and operates meteorological monitoring systems. From these measurement systems, a comprehensive evaluation is conducted to calculate the MEI dose for the Laboratory.

The MEI can be any member of the public at any off-site location where there is a residence, school, business, or office. In 2010, this MEI location was the southernmost building of 2201 Trinity Drive, the Los Alamos Lodge. ${ }^{*}$ Since there are other receptors in the immediate area, all emissions were modeled to the adjacent Airnet Station 257. This station is called the Los Alamos (LA) Inn South station. The primary contributor to the off-site dose measured at this location was resuspension of legacy contamination on the hillside below the Airnet station. Other significant contributors to the reported offsite dose included the potential emissions from non-monitored (minor) emissions sources throughout the Laboratory and emissions of short-lived radioactive gases from the LANSCE accelerator facility. As discussed later in the report, the dose from remediation operations at Materials Disposal Area B (MDA-B) were considered for the MEI location, but measured air concentrations and associated off-site doses were less than the LA Inn South location. Doses reported to the EPA for the past 10 years are shown in Table E1.

\footnotetext{
* After a change in ownership, the Los Alamos Inn was renamed the Los Alamos Lodge. The Airnet station name of "LA Inn South" remains the same for consistency in tracking over the years.
} 
Table E1. Ten-Year Summary of Rad-NESHAP Dose Assessment for LANL

\begin{tabular}{ccl} 
Year & $\begin{array}{c}\text { EDE } \\
\text { (mrem) }\end{array}$ & \multicolumn{1}{c}{ Highest EDE Location } \\
\hline 2001 & 1.84 & 2470 East Road (“East Gate”) \\
2002 & 1.69 & 2470 East Road (“East Gate”) \\
2003 & 0.65 & 2470 East Road ("East Gate”) \\
2004 & 1.68 & 2470 East Road (“East Gate”) \\
2005 & 6.46 & 2470 East Road (“East Gate”) \\
2006 & 0.47 & Los Alamos Airport Terminal \\
2007 & 0.52 & DP Road, Airnet Station 71/326 \\
2008 & 0.55 & 2470 East Road ("East Gate”) \\
2009 & 0.55 & 2470 East Road (“East Gate") \\
2010 & 0.33 & 2201 Trinity Drive, Airnet Station 257 \\
\hline
\end{tabular}

\section{Significant Events}

Several events that took place in 2010 are worth discussion in this Executive Summary.

Commencement of cleanup at Materials Disposal Area B. In February 2009, EPA Region 6 granted initial approval to start cleanup operations at Materials Disposal Area B (MDA-B). Subsequent work scope changes resulted in an update to this Pre-Construction approval, which was submitted in January $2010^{*}$ and approved in February 2010. Initial operations began in February 2010. In June, largescale excavation operations began. Other minor changes to the work scope necessitated communications with EPA Region 6 in October 2010 to address cleanup of residual contamination after a first cycle of excavation had been performed. Later communications in November addressed elevated emissions measurements on the network of air samplers surrounding MDA-B. In January 2011, minor scope changes were made in which much of the MDA-B excavated soil would be re-used at LANL, as long as the soil meets certain criteria for such on-site re-use. Ambient air emissions measurement operations at MDA-B are conducted according to the MDA-B Emissions Management Plan, including actions taken when elevated emissions are measured.

Cleanup work under the American Reinvestment and Recovery Act (ARRA). During CY2010, LANL performed demolition of legacy buildings at Technical Area 21 (TA-21) under the

\footnotetext{
* LA-UR-10-00015, "Update to Pre-Construction Application for the MDA-B Project.” Submitted to EPA Region 6 on January 13, 2010. EPA approval granted February 18, 2010. Files are in the ENV-ES Rad-NESHAP records system.
} 


\section{LANL Radionuclide Air Emissions Report}

ARRA. Operations were described in a letter to EPA Region 6 in May 2010.* By the end of 2010, all legacy plutonium-handling buildings, designated “DP-West,” were torn down to the concrete foundation slab. The legacy tritium-handling buildings at DP-East were torn down as well, including below-grade removal of foundations and subsurface piping, etc. Starting in Fiscal Year 2012, planning will commence for the next phase of activities at TA-21, including remediation of other materials disposal areas (MDA-A and MDA-T), removal of subsurface material at DP-West, and demolition of remaining buildings. RadNESHAP compliance issues have been addressed, and air monitoring stations installed as needed to measure any air emissions from this work.

Addition of two new major point sources at TA-54. Two new waste processing lines were added at TA-54. TA-54 is the site of LANL's low-level radiological waste disposal area, designated Materials Disposal Area G, or Area G. These waste processing lines allow for waste drum repackaging operations and other waste handling processes in preparation for the pending closure of Area $G$, currently scheduled for 2015. As described in the 2009 annual report, the design for these stacks and sampling systems was certified to meet ANSI/HPS N13.1-1999 design criteria using a half-scale model. Operations at TA-54 Building 412 began in June 2010, while operations in Building 231 commenced in September 2010. Emissions from these sources are included in this report.

Installation of new target at LANSCE. The primary beam target/moderator/reflector system was changed out at the LANSCE accelerator facility. One indirect result of that facility improvement was a dramatic reduction in radioactive gas emissions. Levels in 2010 were about one-fifth of levels measured in 2009. As a result, the MEI location was not the East Gate area for 2010.

Site visit by EPA Region 6. The Regional Health Physicist from EPA Region 6 visited LANL in November 2010. Focus areas were a walkaround of MDA-B cleanup operations and TA-21 D\&D activities; the new TA-54 stacks; status of the Chemistry and Metallurgy Research-Replacement (CMRR) facilities; a tour of the Emergency Operations Center, and discussion about National Environmental Policy Act (NEPA) issues with the CMRR facilities. Since this visit was for status updates and information gathering and not a site inspection, no final report or similar summary was issued.

\footnotetext{
* Memo ENV-ES:10-0091, “Rad-NESHAP Status Update of Cleanup Activities at Los Alamos National Laboratory Technical Area 21.” David Janecky to George Brozowski. Technical report designated LA-UR-0907922. Copies available in the ENV-ES records system.
} 
Changes to Radioactive Liquid Waste Treatment Facility. Several changes were made to operations at the TA-50 Building 1 Radioactive Liquid Waste Treatment Facility, the RLWTF. These changes were necessary to meet new NPDES ${ }^{*}$ permit limits that went into effect in August 2010. These changes greatly reduced the volume of radioactive liquid waste (RLW) discharges from the RLWTF. After August, very little treated effluent was discharged through the permitted outfall; rather, other options were used. These included the use of open-air solar evaporative tanks at TA-53 and evaporation of treated RLW in small cooling towers at TA-50. Use of the cooling towers is described later in this report as a "0.1 mrem exemption” under 40CFR61.94(b)(8). In late 2010, a new evaporator was installed at TA-50 to process RLW; operations of that unit started in early 2011. For 2010 reporting, we have addressed the TA-50 cooling tower emissions as part of the Radioactive Materials Usage Survey, appropriate for this minor source. The TA-53 evaporative tanks are an existing LANL source, and emissions from these tanks are measured via the Airnet system of ambient air monitoring stations. The new evaporator at TA-50 will be included in the 2011 Radioactive Materials Usage Survey as a minor source.

Preparation for upgrades of TA-55 stack sampling systems. As part of the TA-55 Reinvestment Project (TRP), the stack sampling systems at LANL's plutonium facility (PF) at TA-55 Building 4 are being upgraded. These upgrades will change the stack samplers from multi-point "rakes" in the rooftop stacks to single-point samplers, designed to meet state-of-the-art requirements of ANSI/HPS N13.1-1999. The rectangular stacks at PF-4 do not meet the ANSI standard requirements for use of single-point samplers, so the new sampling systems will be installed in the exhaust air ductwork in the basement of PF-4, upstream of the stack. Preliminary testing and proof-of-principle measurements were performed in late 2010 and early 2011, with all measurements indicating that the basement ductwork meets all ANSI standard criteria for sampler placement. The upgrade project was temporarily suspended during the federal budget Continuing Resolution, but final design is expected to take place in FY 2012, and construction in FY 2013. Once the new samplers are operational, the multi-point stack samplers currently in the PF-4 stacks will likely be turned off, following a short period of overlap to compare results between the two sampling methods.

\footnotetext{
${ }^{*}$ NPDES is the National Pollutant Discharge Elimination System, water quality discharge limits established by the federal Environmental Protection Agency.
} 


\title{
2010 LANL Radionuclide Air Emissions Report
}

\begin{abstract}
The emissions of radionuclides from Department of Energy Facilities such as Los Alamos National Laboratory (LANL) are regulated by the Amendments to the Clean Air Act of 1990, National Emissions Standards for Hazardous Air Pollutants (40 CFR 61 Subpart H). These regulations established an annual dose limit of 10 mrem to the maximally exposed member of the public attributable to emissions of radionuclides. This document describes the emissions of radionuclides from LANL and the dose calculations resulting from these emissions for calendar year 2010. This report meets the reporting requirements established in the regulations.
\end{abstract}

\section{Section I. Facility Information}

\subsection{4(b)(1) Name and Location of Facility}

Los Alamos National Laboratory (LANL or the Laboratory) and the associated residential areas of Los Alamos and White Rock are located in Los Alamos County in north-central New Mexico, approximately 100 km (60 mi) north-northeast of Albuquerque and 40 km (25 mi) northwest of Santa Fe. Figure 1 illustrates the Laboratory's location with respect to the nation, state, and county.

\subsection{4(b)(2) List of Radioactive Materials Used at LANL}

Since the Laboratory's inception in 1943, its primary mission has been nuclear weapons research and development. Programs include weapons development, nonproliferation, magnetic and inertial fusion, nuclear fission, nuclear safeguards and security, and laser isotope separation. There is also basic research in the areas of physics, chemistry, engineering, and biology.

The primary facilities involved in the emissions of radioactivity are outlined in this section. The facility locations are designated by technical area and building and shown in Figure 2. For example, the facility designation TA-3-29 is Building 29 at Technical Area (TA) 3. Potential radionuclide release points are listed Table 1, with supporting information in later tables and in Section II of this report. Some of the sources described below are characterized as non-point (diffuse and fugitive) emissions. Off-site doses resulting from non-point emissions of radioactive particles and tritium oxide (tritiated water vapor or HTO) are measured and calculated using LANL’s ambient air sampling network (Airnet).

Radioactive materials used at LANL include weapons-grade plutonium, heat-source plutonium, enriched uranium, depleted uranium, and tritium. Also, a variety of materials are generated through the process of activation; consequent emissions occur as gaseous mixed activation products (GMAP) and other particulate or vapor activation products (P/VAP). 


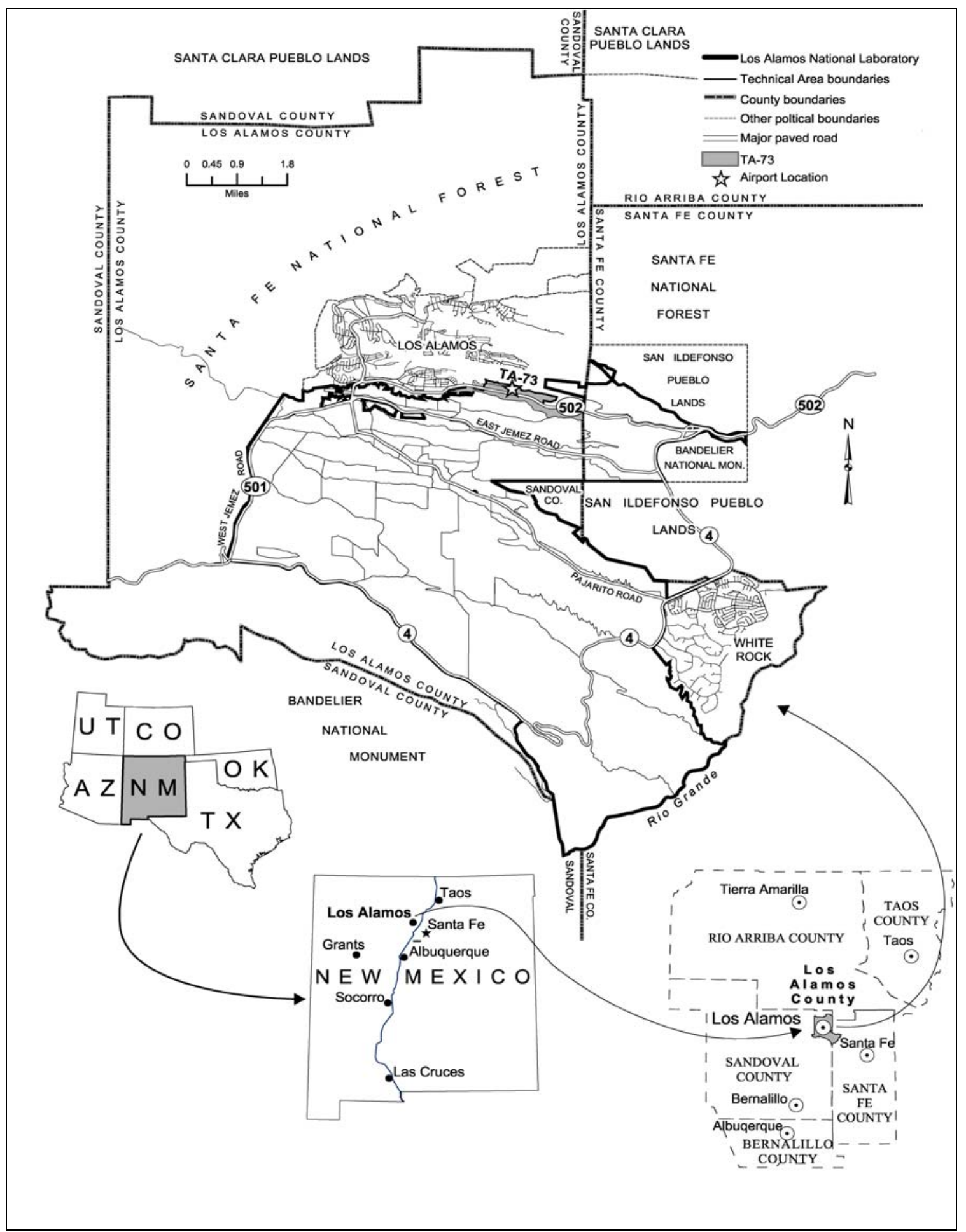

Figure 1. Location of Los Alamos National Laboratory. 


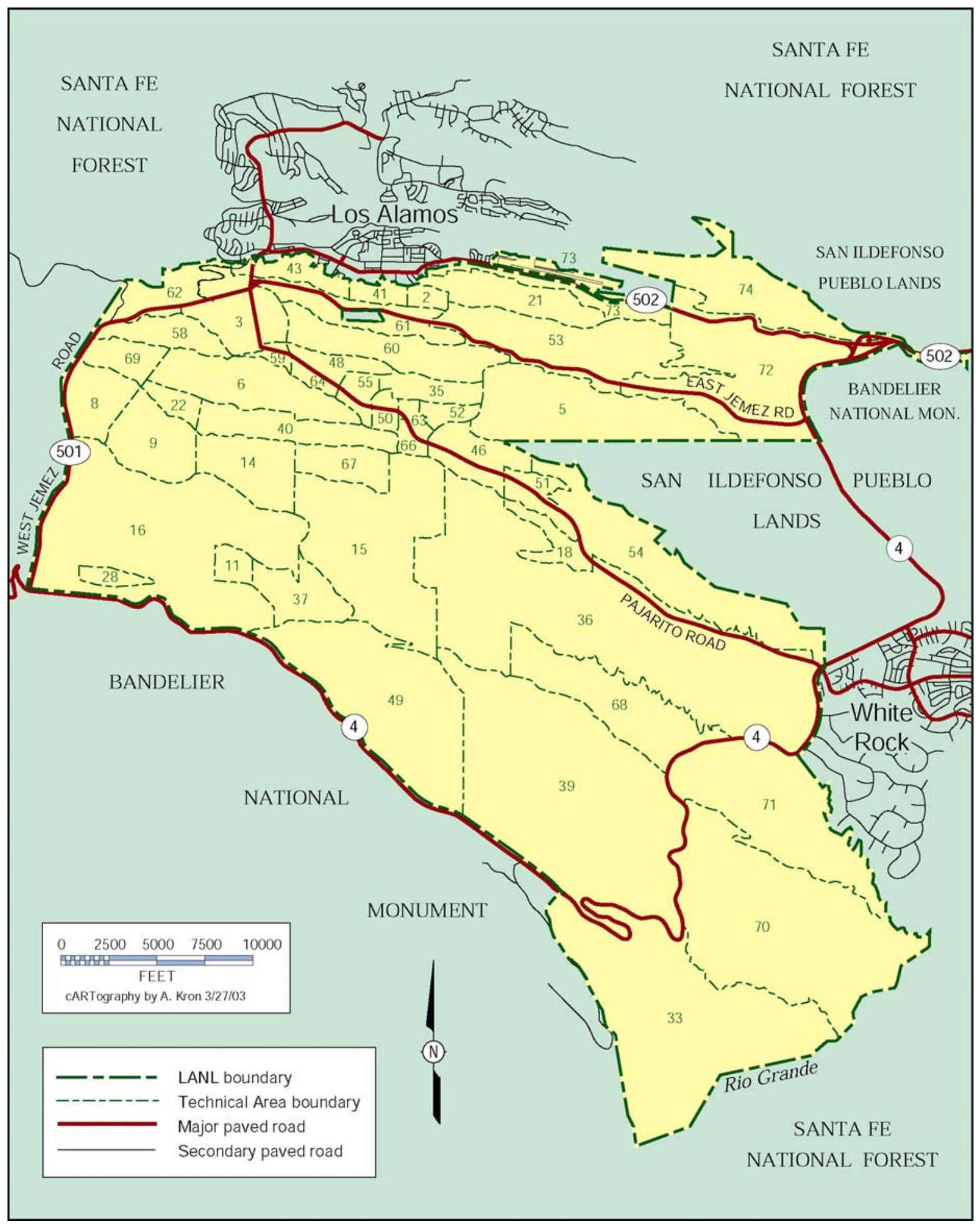

Figure 2. Los Alamos National Laboratory technical areas by number. 


\section{LANL Radionuclide Air Emissions Report}

The radionuclides emitted from point sources at LANL in calendar year 2010 are listed in Table 2. Tritium is released as either tritiated water vapor (called HTO) or elemental tritium gas (HT). Plutonium-239 can also contain Pu-240; the two isotopes are virtually indistinguishable by alpha spectroscopy, but have similar off-site dose conversions. GMAP emissions include ${ }^{41} \mathrm{Ar},{ }^{11} \mathrm{C}$, ${ }^{13} \mathrm{~N}$, and

${ }^{15} \mathrm{O}$. Various radionuclides such as ${ }^{197 \mathrm{~m}} \mathrm{Hg},{ }^{68} \mathrm{Ge}$, and ${ }^{76} \mathrm{Br}$ make up the majority of the P/VAP emissions.

\subsection{4(b)(3) Handling and Processing of Radioactive Materials at LANL Technical Areas}

[Note - numerical superscript references in this and subsequent sections refer to external documents, listed at the end of this report.]

LANL technical areas and operations summaries are listed below. Additional descriptions of LANL technical areas can be found in the Annual Environmental Surveillance Report for LANL. ${ }^{1}$ More thorough descriptions of LANL operations can be found in the Annual Site-Wide Environmental Impact Statement Yearbooks, the most recent being published in $2010 .^{2}$ A complete list of non-monitored sources and activities is found in the Radioactive Materials Usage Survey (RMUS), described in the next section.

The primary facilities responsible for radiological airborne emissions are as follows.

TA-3-29: The Chemistry and Metallurgy Research (CMR) facility conducts chemical and metallurgical research. The principal radionuclides used are isotopes of plutonium as well as other actinides. There are a variety of activities involving plutonium and uranium, which support many LANL and other U.S. Department of Energy (DOE) programs.

TA-3-66: This facility is used for a variety of nuclear materials work, primarily for dealing with metallic and ceramic items, including depleted uranium.

TA-3-102: This machine shop is used for the metalworking of radioactive materials, primarily depleted uranium. The facility only operated for part of 2010, and operations are planning to move to TA-3-141 over the next several years. Currently, TA-3-141 is a non-radiological facility.

TA-3-1698: This facility is designated as the Materials Science Laboratory. The building was designed to accommodate a wide variety of chemicals used in small amounts that are typical of many university and industrial labs conducting research in materials science. Small amounts of radioactive materials are used in experiments on materials properties (e.g., stress/strain measurements). 


\section{LANL Radionuclide Air Emissions Report}

TA-15 and TA-36: These facilities conduct open-air explosive tests involving depleted uranium and weapons development testing. One building, TA-36-99, houses a "gas gun" focused explosive experiment that is ventilated through a non-monitored stack, starting in 2010.

TA-15-312: Dual-Axis Radiographic Hydrodynamic Test (DARHT) Facility: This facility conducts high-explosive-driven experiments to investigate weapons functions and behavior during nonnuclear tests using advanced radiography. Starting in 2007, explosive operations at DARHT are conducted in containment vessels. Use of these vessels virtually eliminates air emissions from these operations. Following testing, vessels undergo cleanout in building 15-534 and at times, repair in building 15-285. Both of these latter two buildings are non-monitored point sources, tracked in the RMUS.

TA-16-205 and -450: Weapons Engineering Tritium Facility (WETF): Buildings 205 and 450 were specifically designed and built to process tritium safely. The operations at WETF are divided into two categories: tritium processing and activities that support tritium processing. Examples of tritiumprocessing operations include the repackaging of tritium into smaller quantities and the packaging of tritium and other gases to user-specified pressures. Other operations include reacting tritium with other materials to form compounds and analyzing the effects of tritium. WETF operations have historically been housed in building 205, while building 450 was built for other tritium activities. In 2007, expansion of WETF into building 450 began. As part of this expansion, exhaust ducts were reconfigured so that emissions from TA-16-205 were routed into the TA-16-450 ES-05 stack. Therefore, the TA-16-205 stack ES-04 is discontinued as a point source and TA-16-450 ES-05 will be the point source for both buildings. The older emissions sampling system for building 205 is located in the exhaust duct coming out of building 16-205, and remains operational and able to measure emissions from that building. The new stack sampling system in stack ES-05 was certified to measure emissions from building 450, whenever that portion of the complex becomes active. This system will also measure emissions from building 205 operations, but was not certified for these operations under ANSI/HPS N13.1-1999 criteria. As discussed in the 2009 emissions report, the ES-05 stack monitor experienced technical problems, and its operations were discontinued in June 2009. Reported emissions for 2010 are measured with the 16-205 duct monitor, but exhausted through and CAP88 modeled from the 16-450 ES-05 stack.

TA-21: Many of the facilities at this decommissioned radiochemistry site are undergoing decontamination and demolition. Some of these operations may contribute to diffuse emissions of uranium and plutonium into the air. The Executive Summary details the current operational state of TA21. The tritium operations in TA-21 were relocated in 2006 to other LANL sites, primarily WETF. In 


\section{LANL Radionuclide Air Emissions Report}

2009, demolition of office and support buildings began. Radiological process buildings were demolished in 2010. The MDA-B legacy waste disposal site is also considered part of TA-21.

TA-41-4: This building was formerly used as a tritium-handling facility. The tritium sources were removed in 2002. Diffuse tritium emissions could result from residual tritium contamination and cleanup operations.

TA-48: The principal activities carried out in this facility are radiochemical separations supporting the medical radioisotope production program, the Yucca Mountain program, nuclear chemistry experiments, and geochemical and environmental research. These separations involve nCi to Ci (hot cell) amounts of radioactive materials and use a wide range of analytical chemical separation techniques, such as ion exchange, solvent extraction, mass spectroscopy, plasma emission spectroscopy, and ion chromatography. Besides the hot cell operations, the building also houses the Actinide Research Facility and includes the other radiochemical operations described above. Building 1 at TA-48 contains the majority of operations and three monitored stacks; smaller operations take place in other buildings around TA-48-1.

TA-50-1: This waste management site consists of an industrial low-level (radioactive) liquid waste treatment facility, RLWTF. The building has one monitored stack (ES-2) and other smaller point sources which are not monitored. The cooling towers mentioned in the executive summary had been used for non-radiological purposes in the past; they began operations to process RLW in 2010. The new evaporator will start radiological operations in 2011 and be tracked as a non-monitored source.

TA-50-37: Currently there are no operations involving radioactive material in this building; long term plans for future operations that involve the use of radioactive actinides have not come to fruition. The operating facility has authorized cessation of stack sampling operations at this location, which is planned for later in 2011.

TA-50-69: This waste management site consists of a waste characterization, reduction, and repackaging facility. There is one monitored stack and two non-monitored stacks at this building. A third non-monitored emissions point, the vacuum pump system discharge, was added for 2010 to ensure completeness of emissions accountability from this building. The vacuum pump system is described in the RMUS as source ID 50006999, and provides suction for the continuous air monitors, fixed air samplers, and the ES-3 stack sampling system. This pump discharges its exhaust directly into the ambient air, and is now considered a separate release point.

TA-53: This technical area houses the Los Alamos Neutron Science Center (LANSCE), a linear particle accelerator complex. There are two monitored stacks (on buildings TA-53-3 and TA-53-7) and 


\section{LANL Radionuclide Air Emissions Report}

several sources tracked in the non-monitored stacks program. The accelerator is used to conduct research in stockpile stewardship, radiobiology, materials science, and isotope production, among other areas. LANSCE consists of the Manuel Lujan Neutron Scattering Center, the Proton Storage Ring, the Weapons Neutron Research facilities, the Proton Radiography facility, and the high-intensity beam line (Line A). The facility accelerates protons and $\mathrm{H}$ - ions to an energy of $800 \mathrm{MeV}$ into target materials such as graphite and tungsten to produce neutrons and other subatomic particles. The design current of the accelerator is approximately 1000 microamperes, but most operations take place as beam currents of 120 microamperes or less. Airborne radioactive emissions result from proton beams and secondary particles passing through and activating air in target cells, beam stop, and surrounding areas, or activating water used in target cooling systems. The majority of the emissions are short-lived activation products such as ${ }^{11} \mathrm{C},{ }^{13} \mathrm{~N}$, and ${ }^{15} \mathrm{O}$. Most of the activated air is vented through the main stacks; however, a fraction of the activated air becomes a fugitive emission from the target areas.

As a by-product of accelerator operations, cooling water can contain trace amounts of radionuclides Two solar evaporative tanks were constructed and began operation in 1999 to evaporate this wastewater from the accelerator. Evaporation of water from these open-air tanks can result in a diffuse source of airborne tritium and other particulates. To support other Laboratory operations, these tanks can be used for evaporation of water from other LANL facilities. As described in the Executive Summary, radioactive liquid waste from TA-50 Building 1 is transported by truck from that facility to the TA-53 evaporative tanks. This happened extensively in late 2010 as surface discharges from the TA-50 RLWTF were minimized.

TA-54: This waste management site consists of active and inactive shallow land burial sites for solid waste and is the primary storage area for mixed and transuranic radioactive waste. Waste characterization and processing operations also take place at TA-54 to prepare waste for shipment to the Waste Isolation Pilot Plant (WIPP). Shipments of transuranic waste for disposal at WIPP began in 1999. Characterization work includes analysis of headspace gases and radiography of waste drum contents; processing includes sorting, segregating, size-reduction, and repackaging of waste.

MDA G at TA-54 is also a known source of diffuse emissions of tritium vapor and direct radiation from above-ground storage of radioactive waste. Resuspension of soil contaminated with low levels of plutonium/americium has also created a diffuse source. Point sources at TA-54 include operations involving characterization, manipulation, or repackaging of waste containers. Two new monitored point sources came on-line in 2010, at Building 412 and Dome 231. These two new sources are waste processing facilities, preparing waste shipments for off-site disposal. 


\section{LANL Radionuclide Air Emissions Report}

TA-55: Building 4 of the Plutonium Facility (PF-4) provides a pit manufacturing capability and continues the role providing the capability for research and development applications in chemical and metallurgical processes for recovering, purifying, and converting plutonium and other actinides. ${ }^{3}$ A wide range of activities (e.g., the heating, dissolution, forming, and welding of special nuclear materials) is also conducted. Additional activities include investigating the means to safely ship, receive, handle, and store nuclear materials and to manage wastes and residues from TA-55. Limited-scope tritium operations also take place in certain areas of TA-55. Building 2 of TA-55 houses associated support facilities for operations in PF-4, including the radiological sample analysis laboratory. Operations from this laboratory are tracked as part of LANL’s non-monitored source program.

\section{Section II. Air Emissions Data}

\subsection{4(b)(4) Point Sources}

Monitored and unmonitored release points at LANL are listed in Table 1. The point sources are identified using an eight-digit identification number for each exhaust stack (StackID); the first two digits represent the LANL technical area, the next four the building, and the last two digits the stack number. Also listed in Table 1 are type, number, and efficiency of the effluent controls used on the release points. More information on effluent controls systems appear below.

In addition to the 26 monitored (“major”) point sources, 31 unmonitored (“minor”) release points in 15 LANL buildings are included in Table 1. Under 40 CFR 61.93(b)(4)(i), sampling of these minor release points is not required because each release point has a potential effective dose equivalent (PEDE) of less than $0.1 \mathrm{mrem} / \mathrm{yr}$ at the critical receptor. However, in order to verify that emissions from unmonitored point sources remain low, LANL conducts periodic confirmatory measurements in the form of the annual Radioactive Materials Usage Survey for Unmonitored Point Sources. ${ }^{4}$ The purpose of this survey is to collect and analyze radioactive materials usage and process information for the unmonitored point sources at LANL. In alternate years, the survey is expanded to review monitored sources and ensure proper emissions monitoring is taking place at these facilities.

The distance between each of the release points and the nearest receptor is provided in Table 1. The nearest receptor can be a residence, school, business, or office. In this report, the nearest receptor is defined as the public receptor most impacted by a given release point; that is, the air dispersion pattern is taken into account to determine the nearest or most critical receptor location.

In compliance with Appendix D to 40 CFR 61, we have used data collected from the facilities in conjunction with engineering calculations and other methods to develop conservative emissions estimates 


\section{LANL Radionuclide Air Emissions Report}

from unmonitored point sources. Estimated PEDEs are calculated by modeling these emissions estimates using the U.S. Environmental Protection Agency (EPA)-approved CAP88 dose modeling software. A comprehensive survey of all of LANL's monitored and unmonitored point sources is conducted annually or biannually, depending on the magnitude of potential emissions. The Laboratory has established administrative requirements to evaluate all potentially new sources. These requirements are established for the review of new Laboratory activities and projects, ensuring that air quality regulatory requirements will be met before the activity or project begins. ${ }^{5}$

\section{Non-point Sources}

There are a variety of non-point sources within the $111 \mathrm{~km}^{2}$ of land (43 square miles) occupied by LANL. Non-point sources can occur as diffuse or large-area sources, or as leaks or fugitive emissions from facilities. Examples of non-point sources of airborne radionuclides include surface impoundments, evaporative tanks and basins, shallow land burial sites, open burn sites, live firing sites, outfalls, container storage areas, unvented buildings, waste treatment areas, solid waste management units, and tanks. Additionally, a building is considered a non-point source if there is no active process exhaust (e.g., no fume hood, glove box, etc.); no forced air exhaust to the environment; or is equipped with only standard heating/ventilating/air conditioning systems (e.g., occupational comfort cooling or heating).

LANL summarizes the potential impacts of non-point sources by analyzing and reporting air concentration measurements of significant radionuclides (other than activation products) collected at ambient air-sampling (Airnet) sites around the Laboratory and at locations of public receptors surrounding the Laboratory. The LANL Airnet system was approved for use in monitoring LANL's nonpoint radioactive air emission sources in $1996 .{ }^{6}$ Based on the original methodology approved by EPA, additional procedures were developed to identify when new Airnet stations were required to assure continued compliance with the Radionuclide NESHAP. ${ }^{7,8}$

\section{Radionuclide Emissions}

Table 2 lists the radionuclides released from monitored point sources, along with the annual emissions in curies for each radionuclide. The point sources are identified using an eight-digit identification number for each exhaust stack: the first two digits represent the LANL technical area, the next four digits the building, and the last two digits the stack number. No detectable emissions are denoted as "none." Extensive notes appear at the end of the source term table. A map showing the general locations of the facilities continuously monitored for radionuclide emissions is shown in Figure 3. 


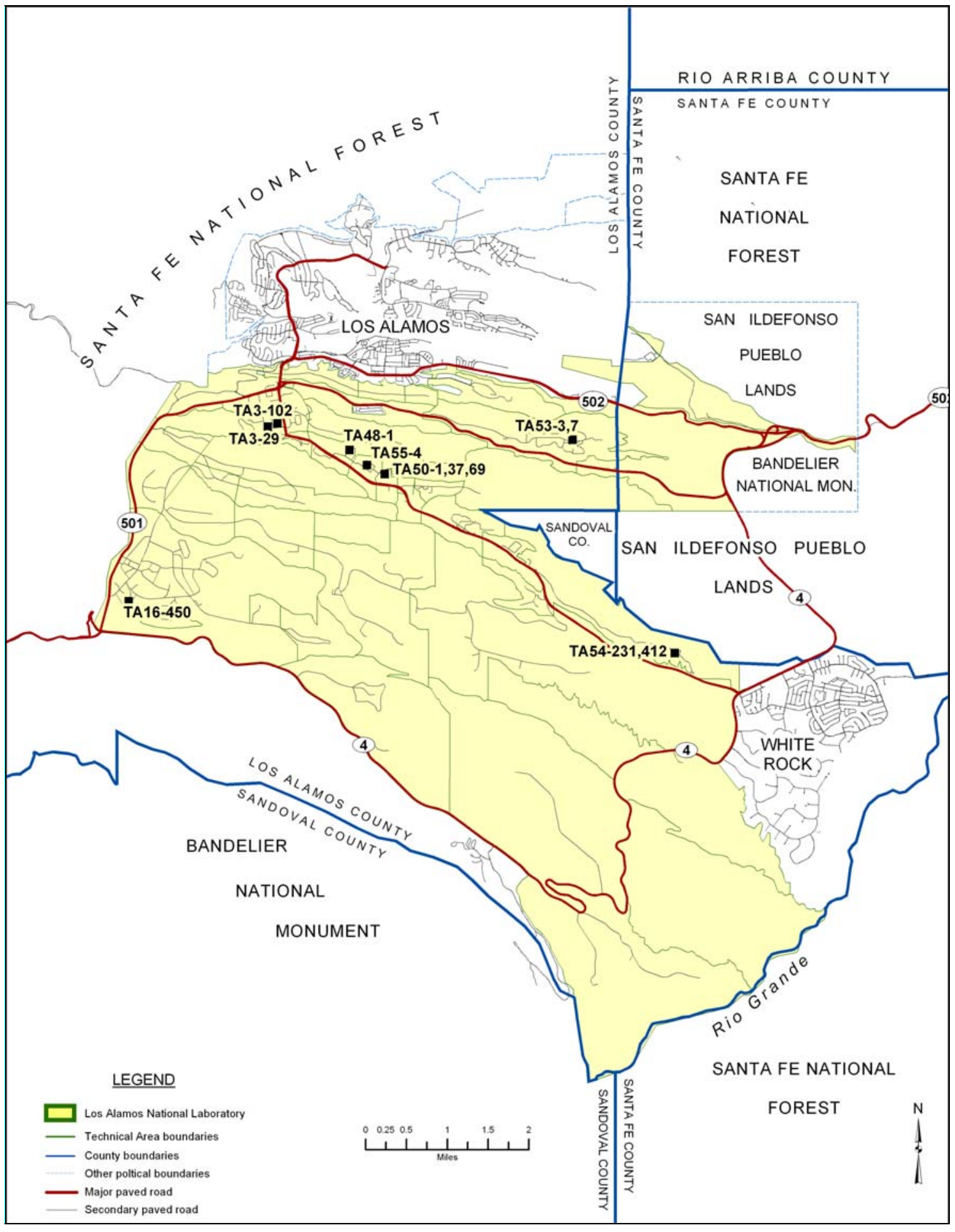

Figure 3. Location of facilities with continuously operated stack-sampling systems for airborne radionuclide emissions. 


\section{LANL Radionuclide Air Emissions Report}

\section{Pollution Controls}

The most common type of filtration for emission control purposes at LANL is the high-efficiency particulate air (HEPA) filter, as noted in Table 1. HEPA filters are constructed of sub-micrometer glass fibers that are pressed and glued into a compact, paper-like, pleated media.

At LANL, each HEPA filter is tested at least once every 12 months. The nominal performance criteria for HEPA filter systems are a maximum penetration of $5 \times 10^{-4}$ for one stage (99.95\% removal) and maximum penetration of $2.5 \times 10^{-7}$ for two stages in series (99.999925\% removal). In these quoted values, filter penetration and percent removal are defined below.

$$
\begin{gathered}
\text { Penetration }=(\text { downstream concentration }) /(\text { upstream concentration }) \\
\text { Removal }=1-(\text { penetration }) * 100 \%
\end{gathered}
$$

Note that in recent years, changes to HEPA filter testing methods and equipment at LANL have resulted in limitations in the ability to certify very high levels of aerosol removal. Therefore, LANL is now only certifying all filters at the "single stage” penetration \& removal criteria, regardless of the number of filter bank stages installed at the facility. Table 1 lists the number of filter banks installed at the facility and the nominal removal efficiency, not the certified tested removal efficiency.

Other types of filters used in ventilation systems are Aerosol 95; RIGA-Flow 220, 221, and 222; and FARR 30/30. These units are typically used as prefilters in HEPA filtration systems. These filters are significantly less efficient than HEPA filters and are typically used for removing gross particulate matter larger than $5 \mu \mathrm{m}$.

The above-mentioned filters are only effective for particles. When the contaminant of concern is in the form of a gas or vapors, activated charcoal beds can be used. Charcoal beds collect the gas contaminant through an adsorption process in which the gas comes in contact with the charcoal and adheres directly to the surface of the charcoal. The charcoal can be coated with different types of materials to make the adsorption process more efficient for specific types of contaminants. Typically, charcoal beds achieve an efficiency of $98 \%$ capture.

Tritium effluent controls are generally composed of a catalytic reactor and a molecular sieve bed. Tritium-contaminated effluent is passed through a catalyst that converts HT into HTO. This HTO is then collected as water on a molecular sieve bed. This process can be repeated until the tritium level is at, or below, the desired level. The effluent is then vented through the stack.

A delay system is used to reduce some of the short-lived radionuclides generated by activation at LANSCE. Emissions from a concentrated source of activated gas (the off-gas system for the 1L target 


\section{LANL Radionuclide Air Emissions Report}

cooling loops) are directed into a long transport line. The transit time through this system allows shortlived gaseous radionuclides to decay before emission from the stack. This delay system is used to provide a reduction in radionuclide emissions from the $1 \mathrm{~L}$ target area.

\section{Compliance with Maintenance and Inspection Requirements under the Revised Rad-NESHAP}

The 2003 revisions to Subpart H established several inspection and maintenance requirements for monitored stacks. These requirements are based on American National Standards Institute/Health Physics Society N13.1-1999, Sampling and Monitoring Releases of Airborne Radioactive Substances from the Stacks and Ducts of Nuclear Facilities. Annual visual inspection of particulate monitoring systems is a component of the Laboratory's program to comply with these requirements. In 2010, we performed stack inspections on 16 monitored stacks. We also performed combination cleaning operations and inspections on an additional 7 stacks. The two new stacks at TA-54 were inspected at the time of installation. For the one tritium stack at TA-16, the annual in-place performance test serves as the annual inspection, per EPA alternative method approval. Two of the monitored stacks do not meet Subpart $\mathrm{H}$ requirements for “major” sources and did not have inspections performed on them. This accounts for the 28 monitored stacks at LANL

Of the 16 inspections performed in 2010, three stack sample systems required cleaning. One has already been addressed in early 2011, and two others will be addressed in the summer of 2011. In 2010, no radiological material was measured on inspection or cleaning equipment. Therefore, no additions to the source term are required from this pathway for 2010.

\section{Section III. Dose Assessment}

\subsection{4(b)(7) Description of Dose Calculations}

Effective dose equivalent (EDE or dose) calculations for point sources, unmonitored point sources, and non-point gaseous activation products from LANSCE were performed with the CAP88 code. Starting with the 2006 annual emissions report, LANL uses CAP88-PC version 3 to demonstrate compliance. Verification of the CAP88 code is performed by running the EPA test case before and after performing the dose calculations. 


\section{LANL Radionuclide Air Emissions Report}

\section{Development of Source Term}

\section{Tritium emissions}

Tritium emissions from the Laboratory's tritium facilities are measured using a collection device known as a bubbler. This device enables the Laboratory to determine not only the total amount of tritium released but also if it is in the chemical form of elemental tritium (HT) or tritiated water vapor (HTO). The bubbler operates by pulling a continuous sample of air from the stack, which is then "bubbled" through three sequential vials containing ethylene glycol. The ethylene glycol collects the water vapor from the sample of air, including any tritium that is part of a water molecule (tritium oxide, or HTO). After bubbling through these three vials, essentially all the water vapor and associated HTO is removed from the air, leaving elemental tritium, or HT. The sample air stream is then passed through a palladium catalyst that converts the HT to HTO. The sample is pulled through three additional vials containing ethylene glycol, which collects the newly formed HTO. The amount of HTO and HT is determined by analyzing the ethylene glycol for the presence of tritium using liquid scintillation counting. Since different chemical forms are collected in different vials, the system will discriminate HTO vapor from HT gas, allowing separate dose assessment with CAP88-PC version 3. For conservatism, however, all tritium is modeled as vapor phase HTO.

Tritium emissions from LANSCE do not require monitoring under 40 CFR 61.93(b)(4)(i). The primary source for airborne tritium emissions at LANSCE is activation of water vapor in air and activation and subsequent evaporation of water in the cooling system of beam targets. Because of the low relative contribution of tritium to the off-site dose at LANSCE, formal monitoring for tritium was discontinued after July 2001. However, the tritium emissions for 2010 can be calculated based on the rate of generation measured in 2001, using representative parameters. Using these rate-of-generation calculations, the tritium emissions from LANSCE stacks in 2010 were calculated to be less than $24 \mathrm{Ci}$ and resulted in less than 0.0075 mrem to the facility critical receptor.

\section{Radioactive particulate emissions}

Emissions of radioactive particulate matter, generated by operations at facilities such as the CMR facility (TA-3-29) and the Plutonium Facility (TA-55), are sampled using a glass-fiber filter. A continuous sample of stack air is pulled through the filter, where small particles of radioactive material are captured. These samples are analyzed weekly using gross alpha/beta counting and gamma spectroscopy to identify any increase in emissions and to identify short-lived radioactive materials. Every six months, LANL composites these stack samples for subsequent analysis at an off-site laboratory. 


\section{LANL Radionuclide Air Emissions Report}

These composite samples are analyzed to determine the total activity of materials such as ${ }^{234} \mathrm{U},{ }^{235} \mathrm{U},{ }^{238} \mathrm{U}$, ${ }^{238} \mathrm{Pu}$, ${ }^{239} \mathrm{Pu}$, and ${ }^{241} \mathrm{Am}$. These data are then combined with estimates of sampling losses and stack and sample flows to calculate emissions. Short-lived progeny are assumed to be emitted in secular equilibrium with their long-lived parent nuclides. For example, we measure for the presence of ${ }^{90} \mathrm{Sr}$ and assume that an equal amount of the progeny ${ }^{90} \mathrm{Y}$ is emitted as well.

\section{Vapor form emissions}

Vapor emissions, generated by LANSCE operations and by hot-cell activities at TA-3-29 and TA-48, are sampled using a charcoal filter or canister. A continuous sample of stack air is pulled through a charcoal filter upon which vaporous emissions of radionuclides are adsorbed. The amount and identity of the radionuclide(s) present on the filter are determined through the use of gamma spectroscopy. This information is then used to calculate emissions. Examples of radionuclides of this type include ${ }^{68} \mathrm{Ge}$ and ${ }^{76} \mathrm{Br}$.

\section{Gaseous mixed activation products (GMAP)}

GMAP emissions resulting from activities at LANSCE are measured using real-time monitoring data. A continuously-operating air flow-through ionization chamber is operated in series with a highpurity germanium detector and data acquisition system. A sample of stack air is pulled through the ionization chamber to measure the total amount of radioactivity in the sample, while specific radioisotopes are identified through the use of gamma spectroscopy and decay curve analysis with the HPGe system. This information is then used to calculate emissions. Radionuclides of this type include ${ }^{11} \mathrm{C},{ }^{13} \mathrm{~N}$, and ${ }^{15} \mathrm{O}$.

\section{Summary of Input Parameters}

EDE to potential receptors was calculated for all radioactive air emissions from sampled LANL point sources. Input parameters for these point sources are provided in Table 3. The geographic locations of the release points, given in New Mexico State Plane coordinates, are provided in Table 4. The relationship of the highest receptor location to the individual release points are provided in Table 5. Other site-specific parameters and the sources of these data are provided in Table 6.

LANL operates an on-site network of meteorological monitoring towers. Data gathered by the towers are summarized and formatted for input to the CAP88 program. For 2010, data from three different towers were used for the air-dispersion modeling; the tower data that are most representative of 
the release point are applied. Copies of the meteorological data files used for the annual 2010 dose assessments are provided in Table 7. Note that due to the extent of the data in Table 7, that table has been moved to Appendix 1. There are three files included in Table 7, detailing wind speed and direction information from TA-6, TA-53, and TA-54 meteorology towers.

The Laboratory also enters population array data to the CAP88 program. The data file represents a 16-sector polar-type array, with 20 radial distances for each sector. Population arrays are developed for each release point using U.S. Census data. An example of the population array used for the LANSCE facility is provided in Table 8. For agricultural array input, LANL is currently using the default values in CAP88. Finally, the radionuclide inputs for the point sources monitored in 2010 are provided in Table 2.

\section{Public Receptors}

Compliance with the annual dose standard is determined by calculating the highest EDE to any member of the public at any off-site point where there is a residence, school, business, or office. The Laboratory routinely evaluates public areas to assure that any new residence, school, business, or office is identified for the EDE calculation. As per EPA guidance, ${ }^{9}$ personnel that work in leased space within the boundaries of the Laboratory are not considered members of the public for the EDE determination. Personnel of this type are considered to be subcontractors to DOE, similar to security guards and maintenance workers.

\section{Point Source Emissions Modeling}

The CAP88 version 3 program was used to calculate doses from both the monitored and unmonitored point sources at LANL. The CAP88 program uses on-site meteorological data to calculate atmospheric dispersion and transport of the radioactive effluents. CAP88 includes all radionuclides for which there are dose conversion factors in the EPA's Federal Guidance Reports. ${ }^{10,11,12}$ In 2010, only three monitored radionuclides were not included in CAP88 for the monitored stacks source term: ${ }^{10} \mathrm{C},{ }^{14} \mathrm{O}$, and ${ }^{16} \mathrm{~N}$. For ${ }^{10} \mathrm{C}$ and ${ }^{14} \mathrm{O},{ }^{11} \mathrm{C}$ was used as a surrogate, as described in the Laboratory procedure ENVEAQ-512. ${ }^{13}$ CAP88 was used to calculate the ${ }^{11} \mathrm{C}$ dose, which was then adjusted for the number of curies emitted, the gamma energy emitted per decay, and the half life of the radionuclides. For ${ }^{16} \mathrm{~N}$, ${ }^{28} \mathrm{Al}$ was used as the surrogate nuclide and the resulting dose was adjusted accordingly. The maximum dose from emissions of radionuclides not included in the CAP88 library was 5.78E-06 mrem (see Tables 12 and 13). This dose contribution is well below the criteria for individual nuclide monitoring, which is $10 \%$ of a 


\section{LANL Radionuclide Air Emissions Report}

source’s PEDE. Updates of “non-CAP88 nuclides” for monitored and non-monitored point sources will be described in an upcoming memo to EPA Region 6 later this summer.

\section{LANSCE Diffuse / Fugitive Emission Modeling}

Some of the GMAP created at the accelerator target cells or at other accelerator beam line locations migrate into room air and into the environment. These diffuse or fugitive sources are continuously monitored throughout the beam-operating period. In 2010, approximately $20 \mathrm{Ci}$ of ${ }^{11} \mathrm{C}$ and $1 \mathrm{Ci}$ of ${ }^{41} \mathrm{Ar}$ were released from LANSCE as fugitive emissions. ${ }^{14}$ These sources were modeled as area sources using CAP88, and the specific input parameters are provided in Table 9.

\section{Environmental Data Used for Non-point Source Emission Estimation}

The net annual average ambient concentration of airborne radionuclides measured at 26 air sampling stations (Figure 4) is calculated by subtracting an appropriate background concentration value. ${ }^{15}$ The net concentration at each air sampler is converted to the annual EDE using Table 2 of Appendix E of 40 CFR 61 and applying the valid assumption that each table value is equivalent to $10 \mathrm{mrem} / \mathrm{yr}$ from all appropriate exposure pathways (100\% occupancy assumed at the respective location). ${ }^{16}$ Dose assessment results from each air sampler are given in Table 10. The operational performance and analytical completeness of each air sampler is provided in Table 11.

In addition to ambient air sampling, the project reviewed one non-point tritium release from TA-16, in which legacy waste equipment was inventoried and processed for disposal. This resulted in a small release of tritium, approximately 10 millicuries. Since the off-site dose impact from this release is less than 0.01 mrem and the emission was measured by ambient air monitoring stations, we are not including this release with the radioactive gas releases in Table 9.

\section{LANSCE Monthly Assessments}

The Laboratory evaluates and reports the dose from short-lived radioactive gases released from LANSCE exhaust stack 53000702 on a monthly basis. This is so we can track and trend the emissions and identify any issues that need addressing throughout the year. The monthly dose values are calculated using actual meteorology for the month and the resulting doses are shown in Table 12. For 2010 the Laboratory also evaluated this stack’s total gaseous emissions for the year in a single CAP88 run and compared the results to the monthly values summed for the calendar year. The sum of monthly doses resulted in a dose of 0.0284 mrem, while the annual total single analysis resulted in a total of 0.0384 mrem. The values differ by about $30 \%$. This difference is due to the annual meteorological file including 


\section{LANL Radionuclide Air Emissions Report}

windy spring season, while the monthly files (starting in June 2010) do not include this season. The southerly spring winds cause higher calculated doses at East Gate (directly north of LANSCE) but lower doses when evaluating other receptors to the west of LANSCE. This issue is made moot by using the maximum value of either the annual evaluation or the sum of the monthly doses for EPA reported doses.

All doses were evaluated at the East Gate receptor location initially; additional receptors were added in later. For later receptors (the LA Inn South Airnet station and 278 DP Road), annual runs were performed and compared with sum of monthly runs as well. The difference between the annual evaluation and the sum of the monthly evaluations was about $30 \%$ for these other receptors. In all cases, the maximum of either the annual GMAP run or the sum of monthly GMAP runs was used for reporting purposes at each analyzed receptor location.

Aside from these monthly GMAP runs from 53000702, all other CAP88 assessments are performed using annual source term and annual meteorological inputs. This decision reflects the yearround sampling for PVAP nuclides, while GMAP is only measured during beam operations. The summary of off-site dose analyses from the LANSCE facility is contained in Table 12.

\section{Highest EDE Determination}

For most of the recent past, the maximally exposed individual (MEI) location has been at 2470 East Road, usually referred to as "East Gate." The dose was mostly a result of LANSCE emissions. Emissions reduction efforts in place at LANSCE since 2005 have resulted in low off-site doses. Emissions were further reduced by improvements made in the new beam Target/Moderator/Reflector System (TMRS) that was installed in early 2010. Because the LANSCE emissions are so low in recent years, the location of the MEI is not as readily apparent as in the past and requires more detailed evaluation, as follows.

We know that the dose from LANSCE emissions is a significant contributor at its facility critical receptor location (East Gate), but much less so at other possible MEI locations. To evaluate different MEI locations, we start by determining the LANSCE at East Gate. We modeled all LANSCE facility emissions to the East Gate location with CAP88. This totaled 0.0699 mrem. To this we added the dose contribution from air concentrations measured at the East Gate Airnet station (0.021 mrem, see Table 10) for a rounded total of 0.091 mrem. This value is the point of comparison for examining the dose at other Airnet locations as reported in Table 10. Airnet station locations with measured doses that exceed this value are subject to further consideration. Airnet measurements are summed with doses from the LANSCE facility emissions, modeled with CAP88 to these alternate locations. Recall that locations must be a school, business, residence, or office to be considered for the MEI. 


\section{LANL Radionuclide Air Emissions Report}

Two Airnet stations with relatively higher doses at MEI locations close to LANSCE were considered. The first location is Airnet station 257, called the LA Inn South station, representing the southernmost building at 2201 Trinity Drive, the Los Alamos Lodge.* The second location is Airnet station 317, adjacent to the MDA-B remediation project, representing a receptor at 278 DP Road. The Airnet dose at the LA Inn location is 0.174 millirem and the dose at the DP Road location is 0.133 millirem for 2010. The LANSCE facility doses at these locations were 0.00404 mrem at LA Inn South and 0.00781 mrem at DP Road. The rounded sums of the Airnet measured dose and the LANSCE facility dose at each location were 0.178 mrem at the LA Inn South location and 0.141 mrem at the DP Road location. The dose of 0.178 mrem at the LA Inn South location was highest so it is the MEI location for 2010 operations. To this total, we add (1) the doses modeled by CAP88 dose from all other LANL facilities to this location and (2) the sum of all non-monitored stack potential emissions as modeled by CAP88 to the individual facility receptors for these non-monitored stacks. Details are in the next section and in Table 13.

It should be noted that there were certain cases where locations with elevated Airnet station measurements were not considered for the location of the MEI. For 2010, these included stations 169, 329, 330, and 331, all along the sections of DP Road north of the MDA-B remediation operations. In these cases, there are no public receptors (business, school, residence, or office) near these Airnet stations; other Airnet stations better represent the air concentrations to which members of the public are exposed. These stations are not considered for the MEI location. Details can be found on the map in Figure 4; measured doses are shown in Table 10.

\subsection{Compliance Assessment}

The highest EDE to any member of the public at any off-site point where there is a residence, school, or business was 0.33 mrem for radionuclides released by LANL in 2010. This dose was calculated by adding up (1) the dose contributions for each of the point sources at LANL, modeled to the MEI location; (2) the diffuse/fugitive gaseous activation products from LANSCE; (3) the dose measured by the ambient air sampler in the vicinity of the public receptor location; and (4) the potential dose contribution of 0.143 mrem from unmonitored stacks. Because the emissions estimates from unmonitored stacks do not account for pollution control systems, the actual dose will be significantly less

\footnotetext{
* After a change in ownership, the Los Alamos Inn was renamed the Los Alamos Lodge. The Airnet station name remains the same for consistency in tracking over the years.
} 


\section{LANL Radionuclide Air Emissions Report}

for these point sources. Table 13 of this report provides the compliance assessment summary, broken down by stack.

The location of the off-site point of highest EDE for 2010 is 2201 Trinity Drive, at the southernmost building of the Los Alamos Lodge complex. For simplicity, CAP88 analyses were made to Airnet Station 257, which is dubbed the "Los Alamos Inn South" Airnet station and adjacent to this MEI

location. Modeling doses to this Airnet location will uniformly represent a cluster of buildings at this location on the south side of Trinity Drive. 


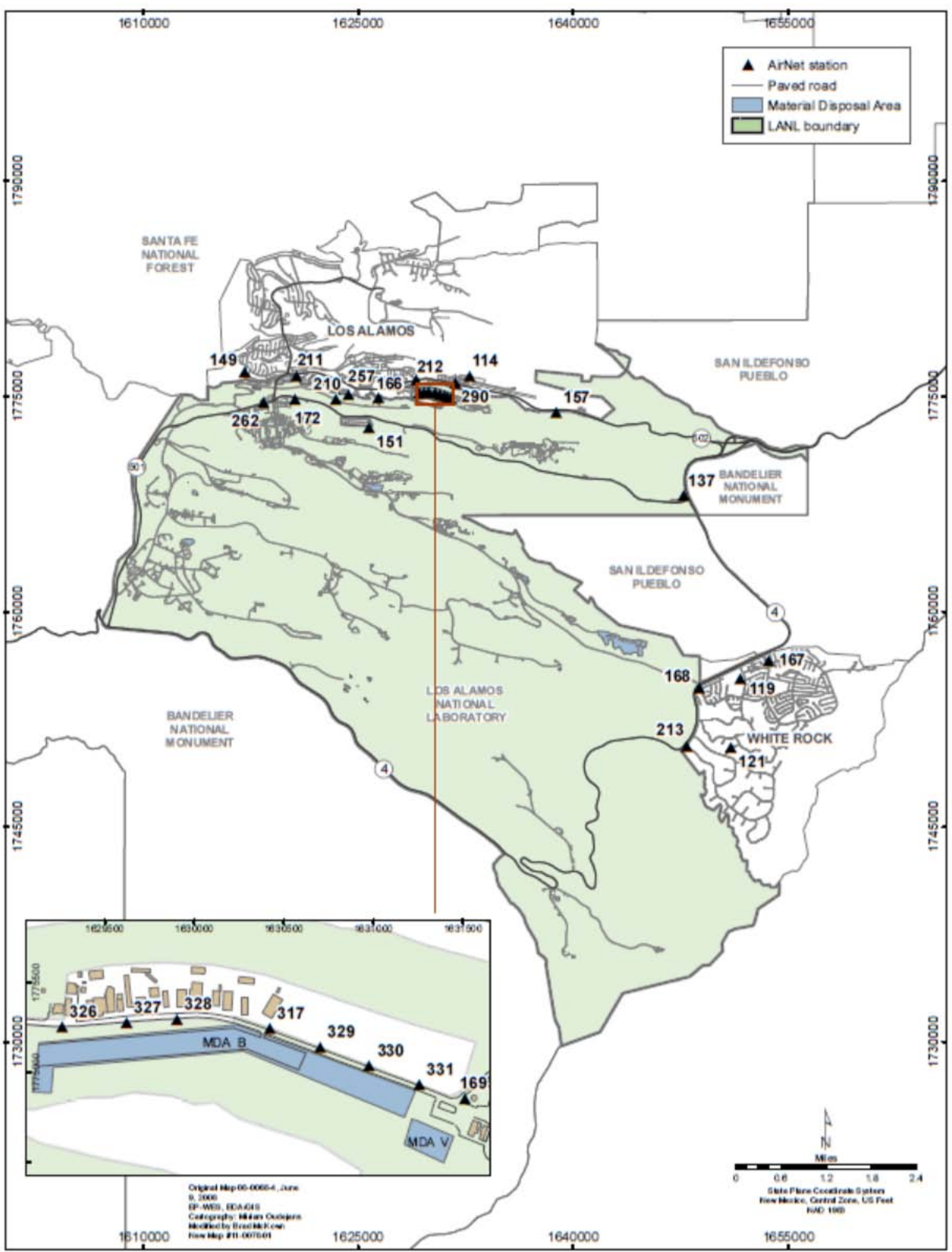

Figure 4. Locations of air sampling stations used for non-point source emissions compliance. 


\section{Section IV. Construction and Modifications}

\subsection{4(b)(8) Constructions, Modifications, and 61.96 Activity Relocations}

A brief description of construction and modifications that were completed in 2010 for which the requirement to apply for approval to construct or modify was waived under 61.96 is listed below:

\section{Gas Gun Experiments}

A series of plate impact experiments on uranium powders and alloys using the gas guns at TA-3969 were conducted in 2010. These experiments were previously conducted at the firing point at TA-3956 and were relocated indoors to take advantage of additional capabilities of the gas guns. Radioactive materials have been used in TA-39-69 previously, but not in the past 10 years. These experiments represent an expansion of existing work.

Gases from these experiments are vented through a HEPA filter and exit the building from a nonmonitored point approximately 10 feet (3 meters) above ground. Emissions were conservatively estimated based on the maximum operating scope, the Appendix D release fraction for particulates, and a release height of 3 meters. With these parameters, CAP88 calculated a worst case uncontrolled dose of less than 2E-7 mrem/yr. Based on actual material usage in 2010, potential emissions from actual operations were estimated at 4E-9 mrem/yr. Potential emissions from these experiments are tracked in the RMUS. These experiments will continue in 2011.

\section{Soil Vapor Extraction Operations}

The soil vapor extraction (SVE) pilot study at TA-54, MDA G, discussed in the 2008 LANL Radionuclide Air Emissions report, was expanded in 2010. LANL is continuing to evaluate the viability of this technique to remove Volatile Organic Compounds from the subsurface plume at TA-54. Due to the presence of tritium in the soil pore gas, this operation is tracked as a potential radiological emission source. Initial emissions estimates for the 2010 work were conservatively calculated based on the highest concentration of tritium found in the pore gas in the area, 100\% release of all tritium, and a full year of continuous operation of the extraction unit. With these parameters, CAP88 calculated a worst-case uncontrolled dose of less than 4.2E-3 mrem/yr. Actual SVE operation in 2010 took place continuously at TA-54, MDA G, from May 9 through May 28, for a total of 480 hours. Based on the 480 hours of actual 
operation, the potential dose for 2010 was 2.3E-4 mrem. While there are no current plans to use SVE at the Laboratory in 2011, this operation could be used in the future.

\section{TA-50 Cooling Towers for Evaporation}

Two small cooling towers, normally used to cool potable water for facility equipment, were used to evaporate treated effluent from the TA-50-1 Radiological Liquid Waste Treatment Facility (RLWTF). This represented a first time use of radioactive materials at these towers. Initial emissions estimates for such use of the cooling towers assumed maximum potential quantity of treated effluent produced in a year, concentration of radionuclides at the highest allowable concentrations, and 100\% radioactive material released. Based on these conservative assumptions, CAP 88 calculated a worst-case off-site dose of less than 0.05 mrem/yr. In 2010, between September and December, 157,261 gallons of treated effluent was evaporated from these towers. Based on the actual amount of radioactive material in this treated effluent, the potential off-dose for 2010 was $2 \mathrm{E}-5$ mrem.

While there are no current plans to use these cooling towers in this manner in 2011, they could be used this way in the future. Any future emissions from these cooling towers will be treated as a point source and emissions will be tracked through RMUS.

\section{Section V. Additional Information}

This section is provided pursuant to DOE guidance and is not required by Subpart $\mathrm{H}$ reporting requirements.

\section{Unplanned Releases}

During 2010, the only instances of increased airborne emissions of radionuclides at the Laboratory were those at MDA-B. Such instances were addressed according to the MDA-B emissions management plan and communicated to EPA Region 6. No other instances of elevated emissions required reporting to the EPA. There were no instances of an unplanned event.

\section{Environmental Monitoring}

In addition to the Airnet monitors identified in this report, additional environmental monitoring stations are operated at LANL and include several environmental monitoring stations located near the LANSCE boundary inhabited by the public. Measurement systems at these stations include 
thermoluminescent dosimeters, continuously operated air samplers, and in-situ high-pressure ion chambers. The combination of these measurement systems allows for monitoring of radionuclide air concentrations and the radiation exposure rate. Results for air sampling associated with NESHAP compliance are included in this document, while results for all monitoring data are published in the Annual Environmental Surveillance Report for DOE Order compliance. This can be found on the web at the following URL: http://www.lanl.gov/environment/air/reports.shtml

\section{Other Supplemental Information}

The following information is included for completeness, but not directly required under 40 CFR 61 Subpart H regulations.

- $\quad$ 80-km collective effective (population) dose equivalent for 2010 airborne releases: 0.218 person-rem

- Compliance with Subparts Q and T of 40 CFR 61-Radon-222 Emissions

These regulations apply to ${ }^{222} \mathrm{Rn}$ emissions from DOE storage/disposal facilities that contain byproduct material. "By-product material" is the tailings or wastes produced by the extraction or concentration of uranium from ore. Although this regulation targets uranium mills, LANL has likely stored small amounts of by-product material used in experiments in the TA-54 low-level waste facility, MDA G; this practice makes the Laboratory subject to this regulation. Subject facilities cannot exceed an emissions rate of $20 \mathrm{pCi} / \mathrm{m}^{2}$ s of ${ }^{222} \mathrm{Rn}$. In 1993 and 1994, LANL conducted a study to characterize emissions from the MDA G disposal site. ${ }^{17}$ This study showed an average emission rate of $0.14 \mathrm{pCi} / \mathrm{m}^{2} \mathrm{~s}$ for MDA G. The performance assessment for MDA G has determined that there will not be a significant increase in ${ }^{222} \mathrm{Rn}$ emissions in the future. ${ }^{18}$

- Potential to exceed 0.1 mrem from LANL sources of ${ }^{222} \mathrm{Rn}$ or ${ }^{220} \mathrm{Rn}$ emissions: not applicable at LANL.

- Status of compliance with EPA effluent monitoring requirements as of June 3, 1996: LANL is in compliance with these requirements. 
Table 1. 40-61.94(b)(4-5) Release Point Data

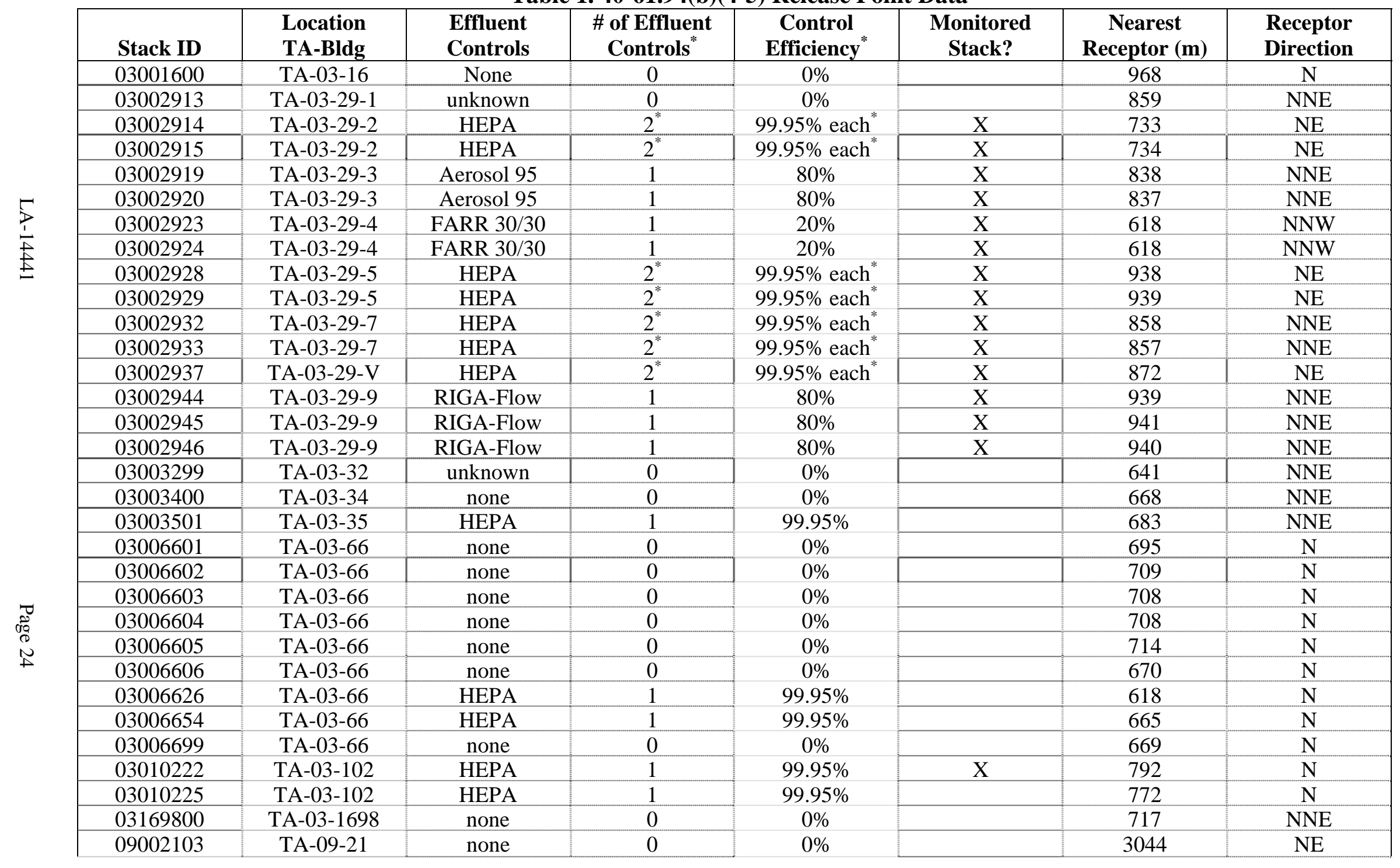


Table 1 (Continued) Release Point Data

\begin{tabular}{|c|c|c|c|c|c|c|c|}
\hline Stack ID & $\begin{array}{l}\text { Location } \\
\text { TA-Bldg }\end{array}$ & $\begin{array}{l}\text { Effluent } \\
\text { Controls }\end{array}$ & $\begin{array}{c}\text { \# of } \\
\text { Effluent } \\
\text { Controls } \\
\end{array}$ & $\begin{array}{c}\text { Control } \\
\text { Efficiency }^{*}\end{array}$ & $\begin{array}{c}\text { Monitored } \\
\text { Stack? }\end{array}$ & $\begin{array}{l}\text { Nearest } \\
\text { Receptor } \\
(\mathbf{m}) \\
\end{array}$ & $\begin{array}{c}\text { Receptor } \\
\text { Direction }\end{array}$ \\
\hline 15053401 & TA-15-534 & HEPA & 1 & $99.95 \%$ & & 3282 & NNE \\
\hline 16020299 & TA-16-202 & unknown & 0 & $0 \%$ & & 1185 & $\mathrm{~S}$ \\
\hline 16045005 & TA-16-450 & none & 0 & $0 \%$ & $\mathrm{X}$ & 772 & $\mathrm{~S}$ \\
\hline 21000507 & TA-21-5 & HEPA & $2^{*}$ & $99.95 \%$ & & 611 & $\mathrm{~N}$ \\
\hline 21015001 & TA-21-150 & HEPA & 1 & $99.95 \%$ & & 595 & $\mathrm{~N}$ \\
\hline 21015505 & TA-21-155 & CR/MS & 1 & $>99 \%$ & & 680 & NNW \\
\hline 21020901 & TA-21-209 & $\mathrm{CR} / \mathrm{MS}$ & 1 & $>99 \%$ & & 712 & NNW \\
\hline 21025704 & TA-21-257 & none & 0 & $0 \%$ & & 601 & $\mathrm{~N}$ \\
\hline 35000200 & TA-35-2 & none & 0 & $0 \%$ & & 1294 & NNW \\
\hline 35021305 & TA-35-213 & none & 0 & $0 \%$ & & 1010 & $\mathrm{~N}$ \\
\hline 36000104 & TA-36-1 & unknown & 0 & $0 \%$ & & 5379 & SE \\
\hline 41000104 & TA-41-1 & HEPA & $2^{*}$ & $99.95 \%$ & & 28 & $\mathrm{~N}$ \\
\hline 41000417 & TA-41-4 & none & 0 & $0 \%$ & & 60 & $\mathrm{~N}$ \\
\hline 43000100 & TA-43-1 & none & 0 & $0 \%$ & & 122 & NNE \\
\hline 46002499 & TA-46-24 & none & 0 & $0 \%$ & & 2887 & $\mathrm{~N}$ \\
\hline 46003100 & TA-46-31 & none & 0 & $0 \%$ & & 2792 & $\mathrm{~N}$ \\
\hline 46004106 & TA-46-41 & none & 0 & $0 \%$ & & 2890 & $\mathrm{~N}$ \\
\hline 46015405 & TA-46-154 & none & 0 & $0 \%$ & & 2769 & $\mathrm{~N}$ \\
\hline 46015899 & TA-46-158 & none & 0 & $0 \%$ & & 3053 & $\mathrm{~N}$ \\
\hline 46020099 & TA-46-200 & none & 0 & $0 \%$ & & 2743 & $\mathrm{~N}$ \\
\hline 48000107 & TA-48-1 & HEPA/Charco & $2^{*}$ & $99.95 \%$ & X & 754 & NNE \\
\hline 48000111 & TA-48-1 & none & 0 & $0 \%$ & & 874 & NNE \\
\hline 48000115 & TA-48-1 & none & 0 & $0 \%$ & & 764 & NNE \\
\hline 48000135 & TA-48-1 & none & 0 & $0 \%$ & & 797 & NNE \\
\hline 48000145 & TA-48-1 & none & 0 & $0 \%$ & & 893 & NNE \\
\hline 48000154 & TA-48-1 & HEPA & $2^{*}$ & $99.95 \%$ & $X$ & 756 & NNE \\
\hline 48000160 & TA-48-1 & HEPA & 1 & $99.95 \%$ & $\mathrm{X}$ & 769 & NNE \\
\hline 48000166 & TA-48-1 & HEPA & $2^{*}$ & $99.95 \%$ & & 867 & NNE \\
\hline 48000167 & TA-48-1 & HEPA & $2^{*}$ & $99.95 \%$ & & 897 & NNE \\
\hline 48000168 & TA-48-1 & none & 0 & $0 \%$ & & 874 & NNE \\
\hline 48004500 & TA-48-45 & none & 0 & $0 \%$ & & 742 & $\mathrm{~N}$ \\
\hline
\end{tabular}


Table 1 (Continued)

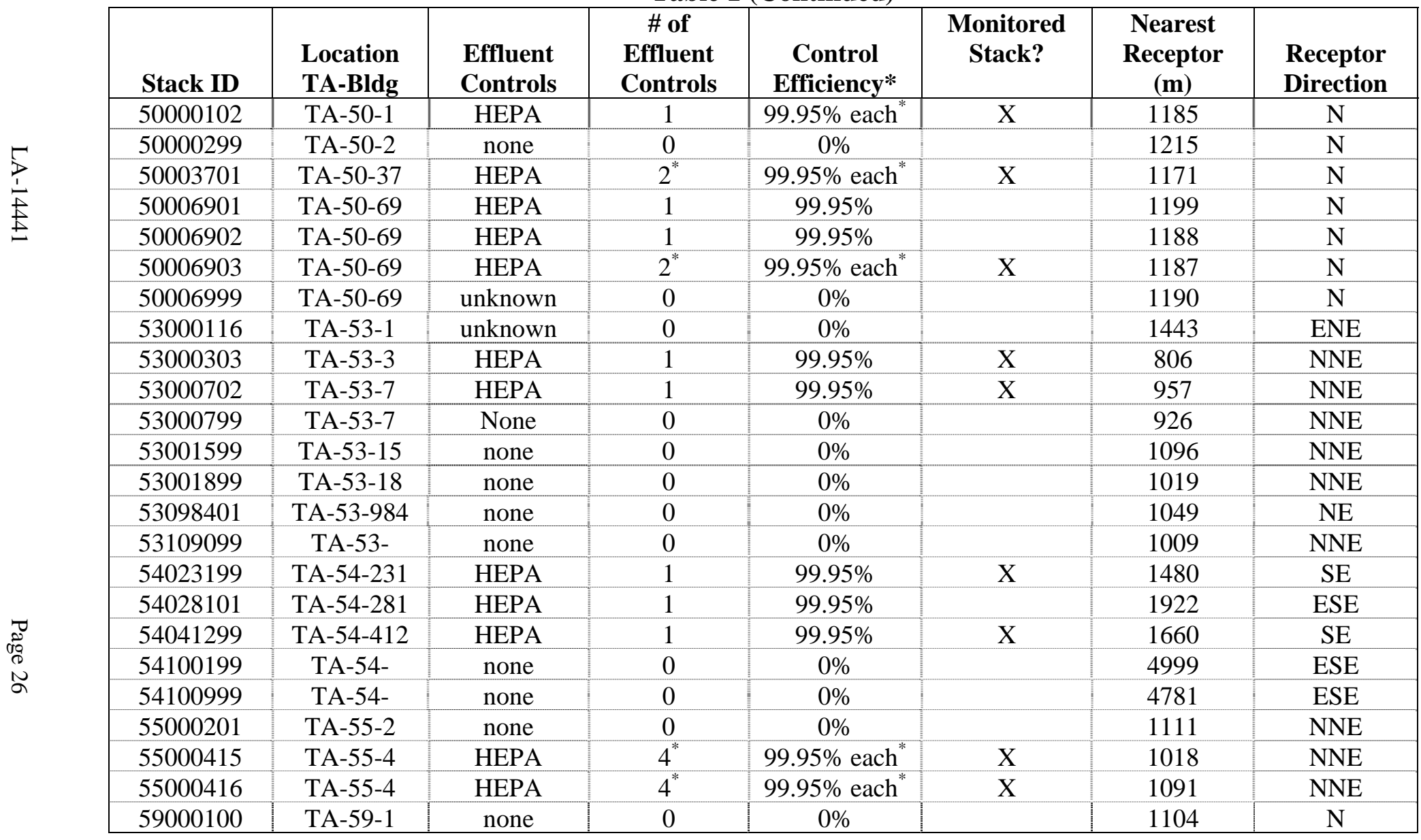

* As described in the main text, LANL only tests HEPA filter banks down to 0.0005 penetration \& 99.95\% removal.

This table reports the actual number of installed HEPA bank stages and nominal removal efficiencies, not tested efficiencies. 
Table 2. 40-61.94(b)(7) User Supplied Data—Radionuclide Emissions

\begin{tabular}{|c|c|c|}
\hline StackID & Nuclide & Emission (Ci) \\
\hline 03002914 & Am-241 & 3.70E-09 \\
\hline 03002914 & Pu-238 & 7.09E-08 \\
\hline 03002914 & Pu-239 & 1.06E-08 \\
\hline 03002914 & Th-228 & 8.52E-09 \\
\hline 03002915 & Am-241 & 3.91E-09 \\
\hline 03002915 & Th-228 & 1.04E-08 \\
\hline 03002915 & U-234 & 5.06E-08 \\
\hline 03002915 & $\mathrm{U}-238$ & $5.38 \mathrm{E}-08$ \\
\hline 03002915 & $\mathrm{~Pa}-234 \mathrm{~m}(\mathrm{p})$ & 5.38E-08 \\
\hline 03002915 & Th-234 (p) & 5.38E-08 \\
\hline 03002919 & Am-241 & 6.09E-07 \\
\hline 03002919 & Pu-238 & 4.18E-07 \\
\hline 03002919 & Pu-239 & 2.92E-06 \\
\hline 03002919 & Sr-90 & 1.47E-08 \\
\hline 03002919 & $Y-90(p)$ & 1.47E-08 \\
\hline 03002919 & Th-228 & 1.29E-08 \\
\hline 03002919 & Th-230 & 1.11E-08 \\
\hline 03002919 & $\mathrm{U}-238$ & 8.03E-08 \\
\hline 03002919 & Pa-234m (p) & 8.03E-08 \\
\hline 03002919 & Th-234 (p) & 8.03E-08 \\
\hline 03002920 & Am-241 & 1.53E-09 \\
\hline 03002920 & Pu-239 & 3.30E-09 \\
\hline 03002920 & Sr-90 & 2.80E-08 \\
\hline 03002920 & $Y-90(p)$ & 2.80E-08 \\
\hline 03002920 & Th-228 & 4.07E-08 \\
\hline 03002920 & Th-230 & 9.75E-09 \\
\hline 03002923 & Pu-238 & 5.90E-09 \\
\hline 03002923 & Sr-90 & 5.22E-08 \\
\hline 03002923 & $Y-90(p)$ & 5.22E-08 \\
\hline 03002923 & Th-230 & 1.86E-08 \\
\hline 03002923 & $U-234$ & 7.43E-07 \\
\hline 03002923 & U-238 & 4.33E-08 \\
\hline 03002923 & $\mathrm{~Pa}-234 \mathrm{~m}(\mathrm{p})$ & 4.33E-08 \\
\hline 03002923 & Th-234 (p) & 4.33E-08 \\
\hline 03002924 & Am-241 & 4.40E-08 \\
\hline 03002924 & Pu-238 & 2.58E-06 \\
\hline 03002924 & Pu-239 & 7.93E-08 \\
\hline 03002924 & Sr-90 & 2.64E-08 \\
\hline 03002924 & $Y-90(p)$ & $2.64 \mathrm{E}-08$ \\
\hline 03002924 & Th-228 & $2.43 E-07$ \\
\hline 03002924 & Th-230 & 4.97E-09 \\
\hline 03002924 & U-234 & 5.76E-06 \\
\hline 03002924 & U-235 & 3.07E-08 \\
\hline 03002928 & Am-241 & $2.86 \mathrm{E}-08$ \\
\hline 03002928 & Pu-238 & 1.59E-06 \\
\hline
\end{tabular}

\begin{tabular}{|c|c|c|}
\hline StackID & Nuclide & Emission (Ci) \\
\hline 03002928 & Pu-239 & 1.51E-07 \\
\hline 03002928 & Th-230 & 8.00E-09 \\
\hline 03002929 & Am-241 & 7.43E-09 \\
\hline 03002929 & Pu-238 & 8.68E-09 \\
\hline 03002929 & Th-230 & $2.28 \mathrm{E}-08$ \\
\hline 03002932 & Am-241 & 3.08E-09 \\
\hline 03002932 & Th-230 & 3.98E-08 \\
\hline 03002932 & U-234 & 6.57E-08 \\
\hline 03002933 & Am-241 & 2.35E-09 \\
\hline 03002933 & $\mathrm{~Np}-237$ & $2.50 \mathrm{E}-07$ \\
\hline 03002933 & Sr-90 & 8.85E-09 \\
\hline 03002933 & $Y-90(p)$ & 8.85E-09 \\
\hline 03002933 & U-238 & $4.66 \mathrm{E}-08$ \\
\hline 03002933 & $\mathrm{~Pa}-234 \mathrm{~m}(\mathrm{p})$ & 4.66E-08 \\
\hline 03002933 & Th-234 (p) & 4.66E-08 \\
\hline 03002937 & Am-241 & 5.83E-11 \\
\hline 03002937 & Sr-90 & $2.08 \mathrm{E}-10$ \\
\hline 03002937 & $Y-90(p)$ & $2.08 \mathrm{E}-10$ \\
\hline 03002937 & U-234 & $6.04 \mathrm{E}-10$ \\
\hline 03002944 & Am-241 & 1.82E-08 \\
\hline 03002944 & Sr-90 & 2.18E-08 \\
\hline 03002944 & $Y-90(p)$ & 2.18E-08 \\
\hline 03002944 & Th-228 & $2.78 E-08$ \\
\hline 03002944 & U-238 & 4.89E-08 \\
\hline 03002944 & $\mathrm{~Pa}-234 \mathrm{~m}(\mathrm{p})$ & 4.89E-08 \\
\hline 03002944 & Th-234 (p) & 4.89E-08 \\
\hline 03002945 & Am-241 & 7.35E-09 \\
\hline 03002945 & Th-228 & $1.04 \mathrm{E}-08$ \\
\hline 03002945 & U-238 & 4.28E-08 \\
\hline 03002945 & $\mathrm{~Pa}-234 \mathrm{~m}(\mathrm{p})$ & 4.28E-08 \\
\hline 03002945 & Th-234 (p) & 4.28E-08 \\
\hline 03002946 & Am-241 & 9.82E-09 \\
\hline 03002946 & Sr-90 & $1.92 E-08$ \\
\hline 03002946 & $Y-90(p)$ & $1.92 \mathrm{E}-08$ \\
\hline 03002946 & Th-228 & 2.16E-08 \\
\hline 03002946 & Th-230 & 2.03E-08 \\
\hline 03010222 & Pu-239 & $6.90 \mathrm{E}-11$ \\
\hline 03010222 & Th-228 & $3.32 E-10$ \\
\hline 03010222 & Th-230 & $1.88 \mathrm{E}-10$ \\
\hline 03010222 & U-234 & 2.59E-09 \\
\hline 03010222 & U-238 & $8.88 E-10$ \\
\hline 03010222 & $\mathrm{~Pa}-234 \mathrm{~m}(\mathrm{p})$ & 8.88E-10 \\
\hline 03010222 & Th-234 (p) & 8.88E-10 \\
\hline 16045005 & H-3(Gas) & $6.11 E+00$ \\
\hline 16045005 & H-3(HTO) & 4.17E+01 \\
\hline
\end{tabular}




\begin{tabular}{|c|c|c|}
\hline StackID & Nuclide & Emission (Ci) \\
\hline 48000107 & As-74 & $1.02 \mathrm{E}-06$ \\
\hline 48000107 & Br-77 & $1.90 \mathrm{E}-04$ \\
\hline 48000107 & Ge-68 & $5.02 \mathrm{E}-03$ \\
\hline 48000107 & Ga-68 (p) & $5.02 \mathrm{E}-03$ \\
\hline 48000107 & Se-75 & $1.04 \mathrm{E}-04$ \\
\hline 48000154 & Sr-90 & $2.36 \mathrm{E}-09$ \\
\hline 48000154 & Y-90 (p) & $2.36 \mathrm{E}-09$ \\
\hline 48000154 & Th-228 & $1.81 \mathrm{E}-09$ \\
\hline 48000154 & Th-230 & $1.08 \mathrm{E}-09$ \\
\hline 48000154 & U-234 & $7.57 \mathrm{E}-09$ \\
\hline 48000160 & As-73 & $6.02 \mathrm{E}-07$ \\
\hline 48000160 & $\mathrm{Br}-77$ & $2.55 \mathrm{E}-06$ \\
\hline 48000160 & Ga-68 (p) & $1.90 \mathrm{E}-05$ \\
\hline 48000160 & Ge-68 & $1.90 \mathrm{E}-05$ \\
\hline 48000160 & Hg-197 (p) & $2.85 \mathrm{E}-05$ \\
\hline 48000160 & Hg-197m & $2.85 \mathrm{E}-05$ \\
\hline 48000160 & Se-75 & $6.81 \mathrm{E}-08$ \\
\hline 50000102 & Am-241 & $3.79 \mathrm{E}-09$ \\
\hline 50000102 & Th-228 & $4.85 \mathrm{E}-08$ \\
\hline 50000102 & U-238 & $7.91 \mathrm{E}-08$ \\
\hline 50000102 & Pa-234m (p) & $7.91 \mathrm{E}-08$ \\
\hline 50000102 & Th-234 (p) & $7.91 \mathrm{E}-08$ \\
\hline 50003701 & None & - \\
\hline 50006903 & Am-241 & $7.77 \mathrm{E}-11$ \\
\hline 50006903 & Pu-238 & $1.20 \mathrm{E}-08$ \\
\hline 50006903 & Pu-239 & $3.86 \mathrm{E}-10$ \\
\hline 50006903 & Th-228 & $1.60 \mathrm{E}-10$ \\
\hline 50006903 & Th-230 & $3.28 \mathrm{E}-10$ \\
\hline 50006903 & U-238 & $9.89 \mathrm{E}-10$ \\
\hline 50006903 & Pa-234m (p) & $9.89 \mathrm{E}-10$ \\
\hline 50006903 & Th-234 (p) & $9.89 \mathrm{E}-10$ \\
\hline 53000303 & Ar-41 & $2.18 \mathrm{E}+00$ \\
\hline 53000303 & $\mathrm{C}-11$ & $5.22 \mathrm{E}+01$ \\
\hline 53000303 & $\mathrm{H}-3(\mathrm{HTO})$ & $1.86 \mathrm{E}+01$ \\
\hline 53000303 & Be-7 & $1.06 \mathrm{E}-03$ \\
\hline 53000303 & Br-76 & $3.37 \mathrm{E}-06$ \\
\hline 53000303 & Br-77 & $9.30 \mathrm{E}-06$ \\
\hline 53000303 & Br-82 & $8.18 \mathrm{E}-05$ \\
\hline 53000303 & Co-60 & $7.34 \mathrm{E}-08$ \\
\hline 53000303 & Ge-68 & $1.99 \mathrm{E}-06$ \\
\hline 53000303 & Ga-68 (p) & $1.99 \mathrm{E}-06$ \\
\hline 53000303 & Na-24 & $3.71 \mathrm{E}-04$ \\
\hline 53000303 & V-48 & $2.97 \mathrm{E}-06$ \\
\hline 53000702 & Ar-11 & $6.41 \mathrm{E}+01$ \\
\hline 53000702 & & \\
\hline 53000702 & $\mathrm{C}-01$ \\
\hline
\end{tabular}

\begin{tabular}{|c|c|c|}
\hline StackID & Nuclide & Emission (Ci) \\
\hline 53000702 & $\mathrm{~N}-13$ & $3.04 \mathrm{E}+01$ \\
\hline 53000702 & $\mathrm{~N}-16$ & 5.75E-01 \\
\hline 53000702 & O-14 & 5.47E-01 \\
\hline 53000702 & $0-15$ & $4.54 \mathrm{E}+01$ \\
\hline 53000702 & $\mathrm{H}-3(\mathrm{HTO})$ & $4.79 \mathrm{E}+00$ \\
\hline 53000702 & As-73 & $6.88 \mathrm{E}-06$ \\
\hline 53000702 & $\mathrm{Br}-76$ & $3.27 E-04$ \\
\hline 53000702 & $\mathrm{Br}-77$ & 3.87E-05 \\
\hline 53000702 & $\mathrm{Br}-82$ & 2.67E-03 \\
\hline 53000702 & $\mathrm{Hg}-197(p)$ & $5.25 E-04$ \\
\hline 53000702 & $\mathrm{Hg}-197 \mathrm{~m}$ & $5.25 E-04$ \\
\hline 53000702 & $\mathrm{Na}-24$ & 1.47E-05 \\
\hline 53000702 & Os-191 & 5.07E-06 \\
\hline 53000702 & Se-75 & 1.82E-05 \\
\hline 54023199 & Am-241 & $2.00 \mathrm{E}-10$ \\
\hline 54023199 & Sr-90 & $7.08 E-10$ \\
\hline 54023199 & $Y-90(p)$ & $7.08 \mathrm{E}-10$ \\
\hline 54041299 & Am-241 & $5.78 \mathrm{E}-11$ \\
\hline 54041299 & Pu-239 & $3.43 E-10$ \\
\hline 54041299 & Th-228 & 5.99E-10 \\
\hline 55000415 & Am-241 & $5.42 E-10$ \\
\hline 55000415 & Pu-238 & $7.11 \mathrm{E}-10$ \\
\hline 55000415 & Pu-239 & $8.00 \mathrm{E}-10$ \\
\hline 55000415 & Th-228 & 8.31E-09 \\
\hline 55000415 & U-234 & $1.29 E-08$ \\
\hline 55000415 & $\mathrm{U}-238$ & 8.73E-09 \\
\hline 55000415 & $\mathrm{~Pa}-234 \mathrm{~m}(\mathrm{p})$ & 8.73E-09 \\
\hline 55000415 & Th-234 (p) & 8.73E-09 \\
\hline 55000416 & Am-241 & 1.51E-09 \\
\hline 55000416 & H-3(Gas) & $9.94 \mathrm{E}+00$ \\
\hline 55000416 & $\mathrm{H}-3(\mathrm{HTO})$ & $6.22 E+00$ \\
\hline 55000416 & Pu-239 & 3.37E-10 \\
\hline 55000416 & Sr-90 & 1.34E-09 \\
\hline 55000416 & $Y-90(p)$ & 1.34E-09 \\
\hline 55000416 & Th-228 & 1.16E-08 \\
\hline 55000416 & Th-230 & 2.68E-09 \\
\hline 55000416 & $\mathrm{U}-238$ & $1.55 E-08$ \\
\hline 55000416 & $\mathrm{~Pa}-234 \mathrm{~m}(\mathrm{p})$ & $1.55 E-08$ \\
\hline 55000416 & Th-234 (p) & 1.55E-08 \\
\hline
\end{tabular}

\begin{tabular}{|l|c|c|}
\hline \multicolumn{3}{|l|}{ Non-Point (Diffuse) Sources } \\
\hline 53DIF1LS & Ar-41 & $3.20 \mathrm{E}-01$ \\
\hline 53DIF1LS & C-11 & $7.79 \mathrm{E}+00$ \\
\hline 53DIF3SY & Ar-41 & $4.90 \mathrm{E}-01$ \\
\hline 53DIF3SY & C-11 & $1.19 \mathrm{E}+01$ \\
\hline
\end{tabular}




\section{LANL Radionuclide Air Emissions Report}

Table 2

Notes: $\quad$ Stacks at the Chemistry \& Metallurgy Research (CMR) facility identified as 03002914 through 03002933 are recorded in the RADAIR database as N3002914 through N3002933, to indicate measurements made with the New sampling systems, effective 2001.

Starting in 2006, particulate emissions from TA-55 stacks 55000415 and 55000416 are measured from new sample systems, which consist of four independent sample systems on each stack. The four samplers are identified as 5500415A, -B, -C, and -D; and 5500416A, -B, -C, and -D. Stack emissions data reported in this table represent average emission values measured from these four samplers. In the RADAIR database, these average emissions are given the stack ID 5500415X and 5500416X, with the " $\mathrm{X}$ " indicating the calculated average value from the four samples. The emissions of tritium (H-3, both HT and HTO forms) from the ES-16 stack use a different sample system, and references remain unchanged in the database.

Radionuclides with the designator "(p)" are short-lived progeny in secular equilibrium with their parent radionuclide; e.g., Ga-68 (progeny) is in equilibrium with Ge-68 (parent).

The term "None" in the Nuclide column indicates that there were no detectable emissions from this source in 2010.

The non-point source at TA-18, designated StackID 18DIFFUS, is no longer reported. Criticality operations at TA-18 have not taken place for several years, and that capability no longer exists at TA-18.

Non-point emissions sources 53DIF3SY and 53DIF1LS are separated from the main source term table because they are addressed in different sections of the annual emissions report.

Stack 16045005 (ES-5) exhausts buildings TA-16-450 and TA-16-205. The ES-5 stack sampler was not operational, so reported emissions are measured by the 16020504 duct sampler. That sampler captures all emissions from the facility, as 16-450 operations have not commenced. A full explanation is in Attachment B. 
Table 3. 40-61.94(b)(7) User-Supplied Data-Monitored Stack Parameters

\begin{tabular}{|c|c|c|c|c|}
\hline StackID & Height (m) & Diameter (m) & Exit Velocity (m/s) & Nearest Meteorological Tower \\
\hline 03002914 & 15.9 & 1.07 & 12.08 & TA-6 \\
\hline 03002915 & 15.9 & 1.05 & 10.59 & TA-6 \\
\hline 03002919 & 15.9 & 1.07 & 14.96 & TA-6 \\
\hline 03002920 & 15.9 & 1.07 & 24.17 & TA-6 \\
\hline 03002923 & 15.9 & 1.07 & 16.99 & TA-6 \\
\hline 03002924 & 15.9 & 1.06 & 19.18 & TA-6 \\
\hline 03002928 & 15.9 & 1.05 & 21.50 & TA-6 \\
\hline 03002929 & 15.9 & 1.07 & 24.19 & TA-6 \\
\hline 03002932 & 15.9 & 1.07 & 17.79 & TA-6 \\
\hline 03002933 & 15.9 & 1.06 & 25.87 & TA-6 \\
\hline 03002937 & 16.8 & 0.20 & 4.51 & TA-6 \\
\hline 03002944 & 16.5 & 1.52 & 9.02 & TA-6 \\
\hline 03002945 & 16.5 & 1.52 & 6.72 & TA-6 \\
\hline 03002946 & 16.5 & 1.88 & 6.33 & TA-6 \\
\hline 03010222 & 13.4 & 0.91 & 0.42 & TA-6 \\
\hline 16045005 & 18.3 & 1.18 & 15.64 & TA-6 \\
\hline 48000107 & 13.4 & 0.30 & 20.60 & TA-6 \\
\hline 48000154 & 13.1 & 0.91 & 5.20 & TA-6 \\
\hline 48000160 & 12.4 & 0.38 & 11.90 & TA-6 \\
\hline 50000102 & 15.5 & 1.82 & 11.87 & TA-6 \\
\hline 50003701 & 12.4 & 0.91 & 5.83 & TA-6 \\
\hline 50006903 & 10.5 & 0.31 & 7.37 & TA-6 \\
\hline 53000303 & 33.5 & 0.91 & 8.00 & TA-53 \\
\hline 53000702 & 13.1 & 0.91 & 8.14 & TA-53 \\
\hline 540023199 & 0.61 & 0.61 & $\begin{array}{c}0 \text { vertical } \\
6.4 \text { horizontal }\end{array}$ & TA-54 \\
\hline 540041299 & 0.61 & 0.61 & $\begin{array}{c}0 \text { vertical } \\
4.2 \text { horizontal }\end{array}$ & TA-54 \\
\hline 55000415 & 9.5 & 0.93 & 7.80 & TA-6 \\
\hline 55000416 & 9.5 & 0.94 & 10.45 & TA-6 \\
\hline
\end{tabular}


Table 4. 61.94(b)(7) User-Supplied Data-Monitored Stack ParametersNM State Plane Coordinates (NAD '83)

\begin{tabular}{|c|c|c|}
\hline StackID & Easting & Northing \\
\hline 03002914 & $1,619,176$ & $1,772,806$ \\
\hline 03002915 & $1,619,171$ & $1,772,805$ \\
\hline 03002919 & $1,619,252$ & $1,772,350$ \\
\hline 03002920 & $1,619,257$ & 1,772,352 \\
\hline 03002923 & $1,618,691$ & $1,772,719$ \\
\hline 03002924 & $1,618,686$ & $1,772,718$ \\
\hline 03002928 & $1,618,774$ & $1,772,265$ \\
\hline 03002929 & $1,618,767$ & $1,772,265$ \\
\hline 03002932 & $1,619,268$ & $1,772,267$ \\
\hline 03002933 & $1,619,272$ & $1,772,269$ \\
\hline 03002937 & 1,618,966 & $1,772,397$ \\
\hline 03002944 & 1,618,987 & $1,772,121$ \\
\hline 03002945 & $1,618,977$ & $1,772,120$ \\
\hline 03002946 & 1,618,982 & $1,772,121$ \\
\hline 03010222 & $1,618,354$ & $1,772,074$ \\
\hline 16045005 & $1,609,426$ & $1,760,910$ \\
\hline 48000107 & $1,623,591$ & $1,770,693$ \\
\hline 48000154 & $1,623,744$ & $1,770,650$ \\
\hline 48000160 & $1,623,613$ & $1,770,638$ \\
\hline 50000102 & $1,626,157$ & $1,769,086$ \\
\hline 50003701 & $1,625,757$ & $1,769,111$ \\
\hline 50006903 & $1,625,579$ & 1,769,065 \\
\hline 53000303 & 1,638,133 & $1,771,546$ \\
\hline 53000702 & $1,638,057$ & $1,771,054$ \\
\hline 54023199 & $1,644,758$ & $1,757,255$ \\
\hline 54041299 & $1,644,568$ & $1,757,946$ \\
\hline 55000415 & $1,624,870$ & $1,769,742$ \\
\hline 55000416 & $1,624,675$ & $1,769,550$ \\
\hline
\end{tabular}


Table 5. 40-61.94(b)(7) User-Supplied Data-Highest Off-Site Dose Location for Monitored Release Points

\begin{tabular}{|c|c|c|c|}
\hline StackID & $\begin{array}{c}\text { Associated } \\
\text { Meteorological Tower } \\
\end{array}$ & $\begin{array}{c}\text { Distance to LANL } \\
\text { Highest Dose Location } \\
\text { (m) }\end{array}$ & $\begin{array}{c}\text { Direction to LANL } \\
\text { Highest Dose Location }\end{array}$ \\
\hline 03002914 & TA-06 & 1,718 & ENE \\
\hline 03002915 & TA-06 & 1,720 & ENE \\
\hline 03002919 & TA-06 & 1,759 & ENE \\
\hline 03002920 & TA-06 & 1,757 & ENE \\
\hline 03002923 & TA-06 & 1,864 & ENE \\
\hline 03002924 & TA-06 & 1,866 & ENE \\
\hline 03002928 & TA-06 & 1,900 & ENE \\
\hline 03002929 & TA-06 & 1,902 & ENE \\
\hline 03002932 & TA-06 & 1,767 & ENE \\
\hline 03002933 & TA-06 & 1,765 & ENE \\
\hline 03002937 & TA-06 & 1,829 & ENE \\
\hline 03002944 & TA-06 & 1,863 & ENE \\
\hline 03002945 & TA-06 & 1,866 & ENE \\
\hline 03002946 & TA-06 & 1,865 & ENE \\
\hline 03010222 & TA-06 & 2,040 & ENE \\
\hline 16045005 & TA-06 & 6,272 & $\mathrm{NE}$ \\
\hline 48000107 & TA-06 & 1,363 & $\mathrm{~N}$ \\
\hline 48000154 & TA-06 & 1,369 & $\mathrm{~N}$ \\
\hline 48000160 & TA-06 & 1,379 & $\mathrm{~N}$ \\
\hline 50000102 & TA-06 & 1,918 & NNW \\
\hline 50003701 & TA-06 & 1,879 & NNW \\
\hline 50006903 & TA-06 & 1,880 & NNW \\
\hline 53000303 & TA-53 & 4,347 & WNW \\
\hline 53000702 & TA-53 & 4,365 & WNW \\
\hline 54023199 & TA-54 & 8,270 & NW \\
\hline 54041299 & TA-54 & 8,089 & NW \\
\hline 55000415 & TA-06 & 1,643 & $\mathrm{~N}$ \\
\hline 55000416 & TA-06 & 1,697 & $\mathrm{~N}$ \\
\hline
\end{tabular}


Table 6. 40-61.94(b)(7) User-Supplied Data-Other Input Parameters

\begin{tabular}{|c|c|c|c|}
\hline Description & Value & Units & $\begin{array}{c}\text { CAP88 Variable Name } \\
\text { (source code/V0 identifiers) }\end{array}$ \\
\hline Annual rainfall rate & 45 & $\mathrm{~cm} / \mathrm{y}$ & RR \\
\hline Lid height & 1600 & $\mathrm{~m}$ & $\mathrm{LIPO}$ \\
\hline Annual ambient temperature & 9 & $\mathrm{deg} \mathrm{C}$ & TA \\
\hline Absolute humidity & 5.5 & $\mathrm{~g} / \mathrm{m}^{3}$ & TG \\
\hline E-vertical temperature gradient & 0.02 & $\mathrm{~K} / \mathrm{m}$ & TG \\
\hline F-vertical temperature gradient & 0.035 & $\mathrm{~K} / \mathrm{m}$ & TG \\
\hline G-vertical temperature gradient & 0.035 & $\mathrm{~K} / \mathrm{m}$ & F1V \\
\hline Food supply fraction - local vegetables & 1 & & F2V \\
\hline Food supply fraction - vegetable regional & 0 & & F3V \\
\hline Food supply fraction - vegetable imported & 0 & & F1B \\
\hline Food supply fraction - meat local & 1 & & F2B \\
\hline Food supply fraction - meat regional & 0 & & F3B \\
\hline Food supply fraction - meat imported & 0 & & F1M \\
\hline Food supply fraction - milk local & 1 & & F2M \\
\hline Food supply fraction - milk regional & 0 & & F3M \\
\hline Food supply fraction - milk imported & 0 & & GSCFAC \\
\hline Ground surface roughness factor & 0.5 & & \\
\hline
\end{tabular}

Table 7: 40-61.94(b)(7) User-Supplied Data-Wind Frequency Arrays

Due to the extent of data reported in Table 7, this table has been moved to Appendix 1. 
Table 8. 40-61.94(b)(7) User-Supplied Data-Population Array

Estimated 2002 Population within $80 \mathrm{~km}$ of Los Alamos National Laboratory (revised 2006)

\begin{tabular}{|c|c|c|c|c|c|c|c|c|c|c|c|c|c|}
\hline \multirow[b]{2}{*}{ Direction } & \multicolumn{13}{|c|}{ Distances from LANSCE stack 53000702 (distances in kilometers) } \\
\hline & $0.0-0.8$ & $0.8-1.0$ & $1.0-2.0$ & 2.0-3.0 & $\begin{array}{l}3.0- \\
4.0\end{array}$ & 4.0-5.0 & $5.0-10$ & $10-20$ & $20-30$ & $30-40$ & $40-50$ & $50-60$ & $60-80$ \\
\hline $\mathbf{N}$ & 0 & 0 & 0 & 157 & 184 & 183 & 0 & 15 & 96 & 1007 & 0 & 884 & 600 \\
\hline NNW & 0 & 0 & 0 & 566 & 276 & 397 & 50 & 7 & 21 & 272 & 0 & 0 & 494 \\
\hline NW & 0 & 0 & 0 & 312 & 647 & 786 & 1336 & 2 & 25 & 52 & 768 & 0 & 1078 \\
\hline WNW & 0 & 0 & 0 & 38 & 959 & 1047 & 5063 & 0 & 33 & 38 & 0 & 0 & 3091 \\
\hline W & 0 & 0 & 0 & 0 & 161 & 169 & 15 & 9 & 78 & 376 & 0 & 88 & 168 \\
\hline WSW & 0 & 0 & 0 & 0 & 0 & 0 & 2 & 9 & 46 & 455 & 0 & 3054 & 0 \\
\hline SW & 0 & 0 & 0 & 0 & 0 & 0 & 5 & 3 & 0 & 0 & 0 & 2591 & 0 \\
\hline SSW & 0 & 0 & 0 & 0 & 0 & 0 & 36 & 4 & 1154 & 1563 & 3708 & 3000 & 65504 \\
\hline$S$ & 0 & 0 & 0 & 0 & 0 & 0 & 20 & 6 & 20 & 179 & 0 & 0 & 3960 \\
\hline SSE & 0 & 0 & 0 & 0 & 0 & 0 & 765 & 46 & 365 & 6118 & 2990 & 0 & 0 \\
\hline SE & 0 & 0 & 0 & 0 & 0 & 0 & 5764 & 1 & 1184 & 79362 & 8866 & 196 & 6 \\
\hline ESE & 0 & 0 & 0 & 0 & 0 & 0 & 36 & 13 & 780 & 9397 & 0 & 721 & 2430 \\
\hline$E$ & 0 & 0 & 0 & 0 & 0 & 0 & 3 & 1720 & 4493 & 459 & 528 & 1 & 598 \\
\hline ENE & 0 & 0 & 0 & 0 & 0 & 0 & 0 & 2336 & 4868 & 3878 & 174 & 1013 & 1752 \\
\hline NE & 0 & 0 & 11 & 0 & 0 & 0 & 0 & 1229 & 15964 & 2692 & 1500 & 1494 & 3527 \\
\hline NNE & 0 & 1 & 22 & 0 & 0 & 0 & 0 & 14 & 2562 & 448 & 3258 & 0 & 58 \\
\hline
\end{tabular}

Table 9. 40-61.94(b)(7) User-Supplied Data-Modeling Parameters for LANL Non-Point Sources

\begin{tabular}{|c|c|c|c|c|c|}
\hline Source & Radionuclide & $\begin{array}{l}\text { Emission } \\
\text { (Ci) }\end{array}$ & $\begin{array}{c}\text { Area of Source } \\
\left(\mathbf{m}^{3}\right)\end{array}$ & $\begin{array}{c}\text { Distance to LANL } \\
\text { Maximum Dose Location } \\
\text { (m) }\end{array}$ & $\begin{array}{c}\text { Direction to LANL } \\
\text { Maximum Dose Location }\end{array}$ \\
\hline TA-53 Beam Switchyard & ${ }^{41} \mathrm{Ar}$ & 4.90E-01 & 484 & 4,299 & WNW \\
\hline StackID = 53DIF3SY & ${ }^{11} \mathrm{C}$ & $1.19 \mathrm{E}+01$ & 484 & 4,299 & WNW \\
\hline TA-53-1L Service Area & ${ }^{41} \mathrm{Ar}$ & 3.20E-01 & 1.0 & 4,351 & WNW \\
\hline Stack ID = 53DIF1LS & ${ }^{11} \mathrm{C}$ & $7.79 \mathrm{E}+00$ & 1.0 & 4,351 & WNW \\
\hline
\end{tabular}


Table 10. Environmental Data-Compliance Stations

\begin{tabular}{|c|c|c|c|c|c|c|c|c|c|c|}
\hline \multicolumn{11}{|c|}{2010 Effective Dose Equivalent measured at air sampling locations around LANL (net millirem) } \\
\hline $\begin{array}{c}\text { New } \\
\text { Site ID }\end{array}$ & \begin{tabular}{|c|} 
Old \\
Site ID \\
\end{tabular} & Site Name & H-3 & Am-241 & Pu-238 & Pu-239 & U-234 & U-235 & U-238 & $\begin{array}{c}\text { Total } \\
\text { (mrem) }\end{array}$ \\
\hline 114 & 9 & LA Airport Terminal Bldg & 0.002 & 0.005 & 0.003 & 0.072 & 0.004 & 0.000 & 0.003 & 0.090 \\
\hline 119 & 13 & Rocket Park & 0.001 & 0.013 & -0.006 & -0.002 & 0.002 & 0.001 & 0.002 & 0.011 \\
\hline 121 & 14 & Pajarito Acres & 0.004 & 0.006 & -0.001 & -0.001 & 0.002 & 0.001 & 0.000 & 0.009 \\
\hline 133 & 17 & Bandelier Fire Lookout & -0.001 & 0.003 & -0.004 & -0.001 & 0.004 & 0.001 & 0.002 & 0.004 \\
\hline 137 & 11 & Well PM-1 & -0.002 & 0.006 & -0.004 & -0.003 & 0.004 & 0.000 & 0.002 & 0.002 \\
\hline 149 & 6 & 48th Street & 0.001 & 0.002 & -0.005 & -0.002 & 0.000 & 0.001 & 0.005 & 0.003 \\
\hline 151 & 12 & Royal Crest Trailer Court & 0.001 & 0.003 & 0.002 & -0.001 & 0.002 & 0.001 & 0.004 & 0.012 \\
\hline 157 & 10 & Eastgate & 0.006 & 0.004 & 0.002 & -0.001 & 0.005 & 0.000 & 0.006 & 0.021 \\
\hline 166 & 8 & McDonalds & 0.003 & 0.003 & 0.001 & 0.004 & 0.006 & 0.001 & 0.004 & 0.022 \\
\hline 167 & 15 & White Rock Fire Station & 0.001 & 0.006 & -0.001 & -0.001 & 0.005 & 0.001 & 0.005 & 0.015 \\
\hline 168 & 16 & WR Nazarene Church & 0.000 & 0.014 & -0.004 & -0.005 & 0.000 & 0.001 & 0.002 & 0.008 \\
\hline 169 & 20 & TA-21 Area B & 0.009 & 0.011 & 0.012 & 0.059 & 0.023 & 0.003 & 0.021 & 0.137 \\
\hline 172 & 32 & LA County Landfill & 0.000 & 0.005 & 0.008 & 0.001 & 0.032 & 0.003 & 0.032 & 0.080 \\
\hline 206 & 90 & Eastgate - Backup & 0.001 & 0.006 & 0.000 & -0.002 & 0.004 & 0.000 & 0.007 & 0.016 \\
\hline 210 & 60 & LA Canyon & 0.000 & 0.001 & 0.000 & 0.005 & 0.003 & 0.001 & 0.003 & 0.012 \\
\hline 211 & 61 & Los Alamos Medical Center & 0.000 & 0.002 & 0.000 & -0.002 & 0.004 & 0.000 & 0.004 & 0.007 \\
\hline 212 & 62 & Crossroads Bible Church & 0.007 & 0.003 & 0.003 & 0.005 & 0.013 & 0.001 & 0.013 & 0.046 \\
\hline 213 & 63 & Monte Rey South & -0.001 & 0.006 & -0.006 & -0.002 & 0.003 & 0.002 & 0.002 & 0.002 \\
\hline 257 & 66 & Los Alamos Inn - South & 0.001 & 0.004 & 0.001 & 0.159 & 0.004 & 0.001 & 0.003 & 0.174 \\
\hline 262 & 67 & TA-3 Research Park & 0.005 & 0.002 & -0.001 & -0.001 & 0.005 & 0.000 & 0.009 & 0.018 \\
\hline 290 & 68 & Los Alamos Airport Road & 0.000 & 0.006 & -0.001 & 0.011 & 0.008 & 0.001 & 0.006 & 0.032 \\
\hline 291 & 18 & DP Rd - West Entrance & 0.003 & 0.007 & 0.002 & 0.035 & 0.023 & 0.002 & 0.020 & 0.092 \\
\hline 307 & 24 & TA-16 & 0.001 & 0.011 & -0.002 & 0.008 & 0.002 & 0.002 & 0.002 & 0.023 \\
\hline 317 & 42 & A15 - West End & 0.005 & 0.003 & 0.003 & 0.088 & 0.019 & 0.002 & 0.013 & 0.133 \\
\hline 318 & 43 & East Road Fire Station & 0.002 & 0.002 & -0.001 & 0.017 & 0.008 & 0.002 & 0.011 & 0.041 \\
\hline 319 & 44 & New Beginnings Church & 0.002 & 0.008 & 0.003 & 0.007 & 0.015 & 0.001 & 0.015 & 0.051 \\
\hline 320 & 46 & HedgeRow East Rd. & -0.004 & 0.006 & 0.000 & 0.012 & 0.010 & 0.001 & 0.011 & 0.035 \\
\hline 326 & 71 & DP - Fire Station & 0.002 & 0.004 & 0.002 & 0.047 & 0.021 & 0.003 & 0.019 & 0.097 \\
\hline 327 & 72 & DP - Ace & 0.003 & 0.004 & 0.003 & 0.043 & 0.014 & 0.001 & 0.011 & 0.080 \\
\hline 328 & 73 & DP - Monitor & 0.006 & 0.002 & 0.002 & 0.040 & 0.020 & 0.002 & 0.020 & 0.092 \\
\hline 329 & 74 & A15 - West Center & 0.029 & 0.003 & 0.008 & 0.893 & 0.032 & 0.002 & 0.021 & 0.988 \\
\hline 330 & 75 & A15 - East Center & 0.021 & 0.005 & 0.005 & 0.678 & 0.032 & 0.002 & 0.017 & 0.759 \\
\hline 331 & 79 & A15 - East End & 0.009 & 0.006 & 0.015 & 0.104 & 0.031 & 0.002 & 0.027 & 0.194 \\
\hline 344 & 19 & Hilltop House & -0.002 & 0.007 & 0.001 & 0.007 & 0.016 & 0.002 & 0.016 & 0.047 \\
\hline 345 & 21 & Canyon School & -0.001 & 0.005 & 0.000 & 0.003 & 0.012 & 0.001 & 0.006 & 0.027 \\
\hline 347 & 28 & Airport Hangers & 0.002 & 0.010 & 0.003 & 0.008 & 0.006 & 0.000 & 0.004 & 0.032 \\
\hline 348 & 29 & State Rd 502/Mid-Runway & 0.004 & 0.021 & 0.000 & 0.003 & 0.008 & 0.001 & 0.006 & 0.043 \\
\hline $\begin{array}{l}\text { Note 1: } \\
\text { Note 2: }\end{array}$ & $\mathrm{ar}$ & Jr & & " (us & & & & & & $\begin{array}{l}\text { 330, } \\
\text { e MEI. }\end{array}$ \\
\hline
\end{tabular}


Table 11. Environmental Data-Compliance Stations

\begin{tabular}{|c|c|c|c|c|c|c|c|c|c|c|}
\hline \multicolumn{11}{|c|}{2010 Analytical Completeness and Air Sampler Operation Summary } \\
\hline $\begin{array}{c}\text { New } \\
\text { Site ID } \\
\end{array}$ & \begin{tabular}{c|} 
Old \\
Site ID
\end{tabular} & Site Name & H-3 & Am-241 & Pu-238 & Pu-239 & U-234 & U-235 & U-238 & $\begin{array}{c}\text { Percent } \\
\text { run time }\end{array}$ \\
\hline 114 & 9 & LA Airport Terminal Bldg & 99.5 & 100 & 100 & 100 & 100 & 100 & 100 & 100 \\
\hline 119 & 13 & Rocket Park & 99.5 & 100 & 100 & 100 & 100 & 100 & 100 & 100 \\
\hline 121 & 14 & Pajarito Acres & 99.4 & 100 & 100 & 100 & 100 & 100 & 100 & 100 \\
\hline 133 & 17 & Bandelier Fire Lookout & 99.1 & 100 & 100 & 100 & 100 & 100 & 100 & 100 \\
\hline 137 & 11 & Well PM-1 & 99.6 & 100 & 100 & 100 & 100 & 100 & 100 & 100 \\
\hline 149 & 6 & 48th Street & 99.5 & 100 & 100 & 100 & 100 & 100 & 100 & 100 \\
\hline 151 & 12 & Royal Crest Trailer Court & 99.6 & 100 & 100 & 100 & 100 & 100 & 100 & 100 \\
\hline 157 & 10 & Eastgate & 99.4 & 100 & 100 & 100 & 100 & 100 & 100 & 100 \\
\hline 166 & 8 & McDonalds & 98.6 & 100 & 96.2 & 100 & 100 & 100 & 100 & 100 \\
\hline 167 & 15 & White Rock Fire Station & 99.6 & 100 & 100 & 100 & 100 & 100 & 100 & 100 \\
\hline 168 & 16 & WR Nazarene Church & 99.5 & 100 & 100 & 100 & 100 & 100 & 100 & 100 \\
\hline 169 & 20 & TA-21 Area B & 99.0 & 100 & 96.2 & 100 & 100 & 100 & 100 & 100 \\
\hline 172 & 32 & LA County Landfill & 98.9 & 100 & 100 & 100 & 100 & 100 & 100 & 100 \\
\hline 206 & 90 & Eastgate - Backup & 98.7 & 100 & 100 & 100 & 100 & 100 & 100 & 100 \\
\hline 210 & 60 & LA Canyon & 99.6 & 100 & 100 & 100 & 100 & 100 & 100 & 100 \\
\hline 211 & 61 & Los Alamos Medical Center & 99.0 & 100 & 100 & 100 & 100 & 100 & 100 & 100 \\
\hline 212 & 62 & Crossroads Bible Church & 99.5 & 100 & 100 & 100 & 100 & 100 & 100 & 100 \\
\hline 213 & 63 & Monte Rey South & 98.6 & 100 & 100 & 100 & 100 & 100 & 100 & 100 \\
\hline 257 & 66 & Los Alamos Inn - South & 99.6 & 100 & 100 & 100 & 100 & 100 & 100 & 100 \\
\hline 262 & 67 & TA-3 Research Park & 99.5 & 100 & 92.3 & 100 & 100 & 100 & 100 & 100 \\
\hline 290 & 68 & Los Alamos Airport Road & 99.6 & 100 & 100 & 100 & 100 & 100 & 100 & 100 \\
\hline 291 & 18 & DP Rd - West Entrance & 99.5 & 100 & 100 & 100 & 100 & 100 & 100 & 100 \\
\hline 307 & 24 & TA-16 & 99.5 & 100 & 100 & 100 & 100 & 100 & 100 & 100 \\
\hline 317 & 42 & A15 - West End & 99.5 & 100 & 100 & 100 & 100 & 100 & 100 & 100 \\
\hline 318 & 43 & East Road Fire Station & 100 & 100 & 100 & 100 & 100 & 100 & 100 & 100 \\
\hline 319 & 44 & New Beginnings Church & 95.3 & 100 & 100 & 100 & 100 & 100 & 100 & 100 \\
\hline 320 & 46 & HedgeRow East Rd. & 99.6 & 100 & 100 & 100 & 100 & 100 & 100 & 100 \\
\hline 326 & 71 & DP - Fire Station & 99.6 & 100 & 100 & 100 & 100 & 100 & 100 & 100 \\
\hline 327 & 72 & DP - Ace & 99.5 & 100 & 100 & 100 & 100 & 100 & 100 & 100 \\
\hline 328 & 73 & DP - Monitor & 99.5 & 100 & 100 & 100 & 100 & 100 & 100 & 100 \\
\hline 329 & 74 & A15 - West Center & 99.4 & 100 & 100 & 100 & 100 & 100 & 100 & 100 \\
\hline 330 & 75 & A15 - East Center & 99.6 & 100 & 100 & 100 & 100 & 100 & 100 & 100 \\
\hline 331 & 79 & A15 - East End & 99.5 & 100 & 100 & 100 & 100 & 100 & 100 & 100 \\
\hline 344 & 19 & Hilltop House & 99.5 & 100 & 100 & 100 & 100 & 100 & 100 & 100 \\
\hline 345 & 21 & Canyon School & 99.5 & 100 & 100 & 100 & 100 & 100 & 100 & 100 \\
\hline 347 & 28 & Airport Hangers & 96.7 & 100 & 100 & 100 & 100 & 100 & 100 & 100 \\
\hline 348 & 29 & State Rd 502/Mid-Runway & 99.5 & 100 & 100 & 100 & 100 & 100 & 100 & 100 \\
\hline Aver & ge Ana & Completeness & for $t$ & $\mathrm{um} \mathrm{H}$ & & & for & rticu & nuc & \\
\hline
\end{tabular}


Table 12. LANSCE Monthly Assessments, Comparison with Annual Analyses, and Facility Dose Summary

\begin{tabular}{|c|c|c|c|c|}
\hline Description & StackID & $\begin{array}{c}\text { Dose at } \\
\text { East Gate } \\
\text { Receptor } \\
\end{array}$ & $\begin{array}{c}\text { Dose at LA } \\
\text { Inn South } \\
\text { Receptor }\end{array}$ & $\begin{array}{c}\text { Dose at } 278 \\
\text { DP Road } \\
\text { Receptor } \\
\end{array}$ \\
\hline LANSCE stack January GMAP & 53000702 & None & None & None \\
\hline LANSCE stack February GMAP & 53000702 & None & None & None \\
\hline LANSCE stack March GMAP & 53000702 & None & None & None \\
\hline LANSCE stack April GMAP & 53000702 & None & None & None \\
\hline LANSCE stack May GMAP & 53000702 & None & None & None \\
\hline LANSCE stack June GMAP & 53000702 & 2.13E-03 & $1.67 \mathrm{E}-04$ & $3.18 \mathrm{E}-04$ \\
\hline LANSCE stack July GMAP & 53000702 & 4.35E-03 & 2.53E-04 & $5.01 \mathrm{E}-04$ \\
\hline LANSCE stack August GMAP & 53000702 & 4.23E-03 & 3.47E-04 & $6.74 \mathrm{E}-04$ \\
\hline LANSCE stack September GMAP & 53000702 & $3.51 \mathrm{E}-03$ & 2.77E-04 & $5.46 \mathrm{E}-04$ \\
\hline LANSCE stack October GMAP & 53000702 & $4.61 \mathrm{E}-03$ & $3.09 \mathrm{E}-04$ & $6.17 \mathrm{E}-04$ \\
\hline LANSCE stack November GMAP & 53000702 & 4.03E-03 & $6.30 \mathrm{E}-04$ & $1.20 \mathrm{E}-03$ \\
\hline LANSCE stack December GMAP & 53000702 & $5.51 \mathrm{E}-03$ & 4.82E-04 & $9.20 \mathrm{E}-04$ \\
\hline $\begin{array}{r}\text { Sum of monthly GMAP runs for this } \\
\text { stack }\end{array}$ & 53000702 & 2.84E-02 & $2.47 \mathrm{E}-03$ & 4.78E-03 \\
\hline $\begin{array}{r}\text { GMAP single annual analysis for this } \\
\text { stack }\end{array}$ & 53000702 & 3.84E-02 & $1.87 \mathrm{E}-03$ & $3.60 \mathrm{E}-03$ \\
\hline
\end{tabular}

To be conservative, the maximum value of the two above methods will be used for all further reporting of GMAP emissions from the main LANSCE stack 53000702. Values are highlighted above for each receptor location.

\begin{tabular}{|c|c|c|c|c|}
\hline & & \multicolumn{3}{|c|}{ Receptor Location..... } \\
\hline \multicolumn{2}{|c|}{ SUMMARY OF LANSCE FACILITY DOSE } & East Gate & LA Inn & 278 DP Rd \\
\hline LANSCE stack GMAP & 53000303 & 8.72E-03 & $6.19 \mathrm{E}-04$ & $1.12 \mathrm{E}-03$ \\
\hline LANSCE stack PVAP & 53000303 & $5.50 \mathrm{E}-03$ & $3.90 \mathrm{E}-04$ & 7.05E-04 \\
\hline LANSCE Non-CAP88 Radionuclides & 53000303 & $0.00 \mathrm{E}+00$ & $0.00 \mathrm{E}+00$ & $0.00 \mathrm{E}+00$ \\
\hline LANSCE stack GMAP (see above) & 53000702 & 3.84E-02 & 2.47E-03 & 4.78E-03 \\
\hline LANSCE stack PVAP & 53000702 & 3.04E-03 & $1.49 \mathrm{E}-04$ & 2.85E-04 \\
\hline LANSCE Non-CAP88 Radionuclides & 53000702 & 5.78E-06 & 2.82E-07 & $1.70 \mathrm{E}-05$ \\
\hline $\begin{array}{l}\text { LANSCE Diffuse/Fugitive Emissions - } \\
\text { Beam Switchyard }\end{array}$ & 53DIF3SY & 9.77E-03 & $2.56 \mathrm{E}-04$ & $5.58 \mathrm{E}-04$ \\
\hline $\begin{array}{l}\text { LANSCE Diffuse/Fugitive Emissions - } \\
\text { 1L Service Area }\end{array}$ & 53DIF1LS & 4.43E-03 & 1.65E-04 & 3.47E-04 \\
\hline 2010 LANSCE & ty summary: & 6.99E-02 & 4.04E-03 & 7.81E-03 \\
\hline $\begin{array}{l}\text { GMAP }=\text { Gaseous Mixed Activation products; } \text { short-liv } \\
\text { PVAP = Particulate \& Vapor Activation Products (e.g. }\end{array}$ & $\begin{array}{l}\text { oactive gases (e.g., } \\
\text { Br-76). }\end{array}$ & $\mathrm{O}-15, \mathrm{Ar}-41)$ & & \\
\hline Note: All CAP88 analyses above are annual assessmen & the exception of $t$ & onthly GMAP & for stack 53 & 2, as described. \\
\hline $\begin{array}{l}\text { Note: For completeness, the "Summary" portion of this } \\
\text { LA Inn South receptor. }\end{array}$ & reproduced in $\mathrm{Ta}$ & 3, next page, & e East Gate & and the \\
\hline
\end{tabular}


Table 13. 40-61.92 Highest Effective Dose Equivalent Summary All LANL Sources

\begin{tabular}{|c|c|c|c|}
\hline Description & StackID & $\begin{array}{l}\text { Dose for Release } \\
\text { Site Receptor }\end{array}$ & $\begin{array}{l}\text { Dose at LA Inn } \\
\text { South Receptor }\end{array}$ \\
\hline CMR Stack - Wing 2 & 03002914 & $8.97 \mathrm{E}-06$ & $3.94 \mathrm{E}-06$ \\
\hline CMR Stack - Wing 2 & 03002915 & 1.96E-06 & 8.67E-07 \\
\hline CMR Stack - Wing 3 & 03002919 & 3.63E-04 & $1.62 \mathrm{E}-04$ \\
\hline CMR Stack - Wing 3 & 03002920 & $3.24 \mathrm{E}-06$ & $1.30 \mathrm{E}-06$ \\
\hline CMR Stack - Wing 4 & 03002923 & 4.27E-06 & $2.54 \mathrm{E}-06$ \\
\hline CMR Stack - Wing 4 & 03002924 & $1.87 \mathrm{E}-04$ & $1.12 \mathrm{E}-04$ \\
\hline CMR Stack - Wing 5 & 03002928 & $1.13 \mathrm{E}-04$ & $5.50 \mathrm{E}-05$ \\
\hline CMR Stack - Wing 5 & 03002929 & $1.32 \mathrm{E}-06$ & $6.25 \mathrm{E}-07$ \\
\hline CMR Stack - Wing 7 & 03002932 & $1.58 \mathrm{E}-06$ & 6.99E-07 \\
\hline CMR Stack - Wing 7 & 03002933 & $9.21 \mathrm{E}-06$ & $3.71 \mathrm{E}-06$ \\
\hline CMR Stack - Vault & 03002937 & $0.00 \mathrm{E}+00$ & $0.00 \mathrm{E}+00$ \\
\hline CMR Stack - Wing 9 & 03002944 & $3.24 \mathrm{E}-06$ & $1.61 \mathrm{E}-06$ \\
\hline CMR Stack - Wing 9 & 03002945 & 1.43E-06 & 7.34E-07 \\
\hline CMR Stack - Wing 9 & 03002946 & $2.57 \mathrm{E}-06$ & $1.30 \mathrm{E}-06$ \\
\hline Shops Addition Stack & 03010222 & $1.91 \mathrm{E}-08$ & 9.05E-09 \\
\hline WETF Stack - new & 16045005 & $7.62 \mathrm{E}-03$ & $1.57 \mathrm{E}-03$ \\
\hline Radiochemistry Stack & 48000107 & $1.14 \mathrm{E}-02$ & $3.70 \mathrm{E}-03$ \\
\hline Radiochemistry /non-CAP88 nuclides & 48000107 & None & None \\
\hline Radiochemistry Stack & 48000154 & $3.16 \mathrm{E}-07$ & 9.77E-08 \\
\hline Radiochemistry Stack & 48000160 & 4.55E-05 & $1.47 \mathrm{E}-05$ \\
\hline Waste Management Stack & 50000102 & $1.76 \mathrm{E}-06$ & $6.46 \mathrm{E}-07$ \\
\hline Waste Management Stack & 50003701 & none & none \\
\hline Waste Management Stack & 50006903 & $6.56 \mathrm{E}-07$ & $2.20 \mathrm{E}-07$ \\
\hline LANSCE-Stack - GMAP & 53000303 & $8.72 \mathrm{E}-03$ & 6.19E-04 \\
\hline LANSCE- Annual - Partic/Vapor & 53000303 & $5.50 \mathrm{E}-03$ & 3.90E-04 \\
\hline LANSCE Non-CAP88 radionuclides & 53000303 & $0.00 \mathrm{E}+00$ & $0.00 \mathrm{E}+00$ \\
\hline LANSCE-Stack - GMAP (See Note below) & 53000702 & 3.84E-02 & 2.47E-03 \\
\hline LANSCE- Annual - Partic/Vapor & 53000702 & $3.04 \mathrm{E}-03$ & 1.49E-04 \\
\hline LANSCE Non-CAP88 radionuclides & 53000702 & $5.78 \mathrm{E}-06$ & 2.82E-07 \\
\hline LANSCE Fugitive - Beam Switch Yard & 53DIF3SY & 9.77E-03 & $2.56 \mathrm{E}-04$ \\
\hline LANSCE Fugitive - 1L Service Area & 53DIF1LS & 4.43E-03 & $1.65 \mathrm{E}-04$ \\
\hline Waste Processing Stack & 54023199 & $0.00 \mathrm{E}+00$ & $0.00 \mathrm{E}+00$ \\
\hline Waste Processing Stack & 54041299 & $0.00 \mathrm{E}+00$ & $0.00 \mathrm{E}+00$ \\
\hline Plutonium Facility Stack & 55000415 & 7.61E-07 & 2.67E-07 \\
\hline Plutonium Facility Stack & 55000416 & 4.63E-03 & 1.73E-03 \\
\hline Unmonitored Stacks - No credit for controls & 99000000 & 1.43E-01 & 1.43E-01 \\
\hline Air Sampler Net Dose @ this location & 99000010 & N/A & $1.74 \mathrm{E}-01$ \\
\hline \multicolumn{3}{|c|}{ Total maximally exposed individual dose (mrem) } & 0.328 \\
\hline \multicolumn{3}{|c|}{ Rounded total for reporting purposes (mrem) } & 0.33 \\
\hline \multicolumn{4}{|c|}{$\begin{array}{l}\text { Note 1: As described in Table 12, the reporting value for GMAP emissions from } 53000702 \text { is the maximum value } \\
\text { of either the annual GMAP dose assessment or the sum of monthly GMAP dose assessments. Data for } \\
\text { TA-53 stacks here is reproduced from Table } 12 \text {. }\end{array}$} \\
\hline
\end{tabular}




\section{LANL Radionuclide Air Emissions Report}

\subsection{4(b)(9) Certification}

I certify under penalty of law that I have personally examined and am familiar with the information submitted herein and based on my inquiry of those individuals immediately responsible for obtaining the information, I believe that the submitted information is true, accurate, and complete. I am aware that there are significant penalties for submitting false information including the possibility of fine and imprisonment. See 18 U.S.C. 1001.

Signature:

$<$ signature on file $>$

Date:

$6 / 21 / 2011$

Kevin W. Smith, Owner

Manager

Los Alamos Site Office

National Nuclear Security Administration

U.S. Department of Energy

Signature:

$<$ signature on file $>$

Date:

$6 / 20 / 2011$

J. Chris Cantwell, Operator

Associate Director

Environment, Safety, Health and Quality Division

Los Alamos National Security, LLC

Los Alamos National Laboratory 


\section{LANL Radionuclide Air Emissions Report}

\section{References}

1. Los Alamos National Laboratory, “Environmental Surveillance at Los Alamos during 2009,” LA14427-ENV, September 2010.

2. Los Alamos National Laboratory, “SWEIS Yearbook—2008,” LA-UR-10-03439, 2010.

3. U.S. Department of Energy, "Site-Wide Environmental Impact Statement for Continued Operation of the Los Alamos National Laboratory” DOE/EIS-0380, 2009.

Available on the Web at: http://www.doeal.gov/laso/NEPASWEIS.aspx

4. $\quad$ R. Sturgeon, “2010 Radioactive Materials Usage Survey for Unmonitored Point Sources,” ENV-ES:11-140 (pending final publication at time of report development).

5. Los Alamos National Laboratory Procedure, “Air Quality Reviews,” P408, December 2010.

6. U.S. Environmental Protection Agency, Federal Register, Vol. 60, No. 107, June 5, 1995.

7. Los Alamos National Laboratory Procedure, "Evaluating New Diffuse Sources and New Receptors for AIRNET Coverage,” ESH-17-238, R0, December 2001.

8. Letter to Mr. George Brozowski, Radiation Program Manager, Environmental Protection Agency from Mr. Steve Fong, Office of Environment, Department of Energy, May 11, 2001.

9. Frank Marcinowski, Acting Director, Radiation Protection Division, "Criteria to Determine Whether a Leased Facility at Department of Energy (DOE) is Subject to Subpart H," Office of Radiation and Indoor Air, U.S. Environmental Protection Agency, March 26, 2001.

10 K. F. Eckerman, A. B. Wolbarst, and A. C. B. Richardson, Federal Guidance Report No. 11, "Limiting Values of Radionuclide Intake and Air Concentration and Dose Conversion Factors for Inhalation, Submersion, and Ingestion,” Office of Radiation Programs, U.S. Environmental Protection Agency, Washington, D.C., 1988.

11. K. F. Eckerman and J. C. Ryman, Federal Guidance Report No. 12, "External Exposures to Radionuclides in Air, Water, and Soil Exposure-to-Dose Coefficients for General Application,” U.S. Environmental Protection Agency, Washington, D.C., 1993.

12. K. F. Eckerman, R. W. Leggett, C. B. Nelson, J. S. Puskin, and A. C. B. Richardson, Federal Guidance Report No. 13, "Cancer Risk Coefficients for Environmental Exposure to Radionuclides,” U.S. Environmental Protection Agency, Washington, D.C., 1999.

13. Los Alamos National Laboratory Procedure, "Dose Factors for Non-CAP88 Radionuclides," ENV-EAQ-512, November 2009.

14. Los Alamos National Laboratory, "2010 Annual Source Term for Radionuclide Air Emissions,” ENV-ES:11-0100, May 16, 2011.

15 Los Alamos National Laboratory Procedure, “Air Pathway Dose Assessment,” ENV-EAQ-502, September 2009.

16. U.S. Environmental Protection Agency, "National Emission Standards for Emissions of Radionuclides Other than Radon from Department of Energy Facilities," Code of Federal Regulations, Title 40, Part 61.90, Subpart H, 1989.

17. Bart Eklund, "Measurements of Emission Fluxes from Technical Area 54, Areas G and L," Radian Corporation report, Austin, Texas, 1995.

18. Los Alamos National Laboratory, "Performance Assessment and Composite Analysis for Los Alamos National Laboratory Materials Disposal Area G,” LA-UR-97-85, 1997. 


\section{Appendix 1 - Meteorology Data \\ Due to the extent of data reported in Table 7, that table has been moved to this appendix.}

Table 7: 40-61.94(b)(7) User-Supplied Data-Wind Frequency Arrays

Table 7a: CAP88 Input Data for 2010 TA-6 Meteorological Tower (98.3\% Data Completeness)

N A 0.000640 .000200 .000000 .000000 .000000 .00000

NNE A 0.000780 .000200 .000030 .000000 .000000 .00000

NE A 0.001220 .000320 .000000 .000000 .000000 .00000

ENE A $\odot .002000 .000550 .000000 .000000 .000000 .00000$

E A 0.002180 .000670 .000000 .000000 .000000 .00000

ESE A 0.002030 .000730 .000000 .000000 .000000 .00000

SE A $0.001420 .000900 .000000 .000000 .0000 \odot \odot .000 \odot \odot$

SSE A 0.001250 .000900 .000000 .000000 .000000 .00000

S A 0.001040 .000670 .000000 .000000 .000000 .00000

SSW A ๑. 000700.000170 .000000 .000000 .000000 .00000

SW A 0.000580.000320.000000.000000.000000.00000

WSW A 0.000320 .000150 .000000 .000000 .000000 .00000

W A 0.000290 .000230 .0000000 .000000 .000000 .00000

WNW A 0.000290.000170.000000.000000.000000.00000

NW A 0.000460.000260.000060.000000.000000.00000

NNW A ๑.0000350.000290.000000.000000.000000.00000

N B 0.000230 .000090 .000000 .000000 .000000 .00000

NNE B $0.0000350 .000170 .000000 .000000 .000000 .0000 \odot$

NE B 0.000580 .000460 .000000 .000000 .000000 .00000

ENE B 0.000870 .000810 .000000 .000000 .000000 .00000

E B ०.001070.001020.000000.000000.000000.00000

ESE B 0.001100 .001510 .000000 .000000 .000000 .00000

SE B 0.000930 .001940 .000000 .000000 .000000 .00000

SSE B $0.000610 .001540 .000000 .000000 .000000 .0000 \odot$

S B 0.000380 .001310 .000000 .000000 .000000 .00000

SSW B 0.000120 .000440 .000000 .000000 .000000 .00000

SW B ०.000090.000320.000030.000000.000000.00000

WSW B 0.000120 .000200 .000000 .000000 .000000 .00000

W B 0.000030 .000170 .0000030 .000000 .000000 .00000

WNW B ०.000060.000090.000060.000000.000000.00000

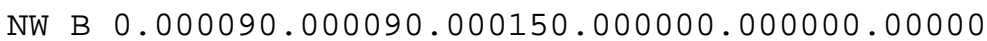

NNW B $\odot .000120 .000170 .000030 .000000 .000000 .00000$

N C 0.000230 .000520 .000030 .000000 .000000 .00000

NNE C 0.000520 .000870 .000000 .000000 .000000 .00000

NE C 0.000780 .001600 .000120 .000000 .000000 .00000

ENE C ०.002090.002670.000060.000000.000000.0000९

E C 0.002610 .003890 .000000 .000000 .000000 .00000

ESE C 0.001420 .004320 .000030 .000000 .000000 .00000

SE C 0.001540 .006040 .000060 .000000 .000000 .00000

SSE C 0.000810 .007400 .000350 .000000 .000000 .00000

S C 0.000640 .005570 .001310 .000000 .000000 .00000

SSW C 0.000410 .002320 .000840 .000030 .000000 .00000

SW C 0.000120 .001310 .000150 .000000 .000000 .00000

WSW C 0.000170 .000670 .000350 .000000 .000000 .00000

W C 0.000090 .000610 .0000490 .000030 .0000000 .00000

WNW C 0.0000030 .000520 .000260 .000000 .000000 .00000

NW C 0.000200 .000610 .000440 .000000 .000000 .00000

NNW C ०.000060.000670.000090.000030.000000.0000९

N D 0.004560 .005920 .003020 .000990 .000060 .00003 


\section{Table 7a (continued)}

NNE D ०.004620.009140.005370.001540.000030.0000९

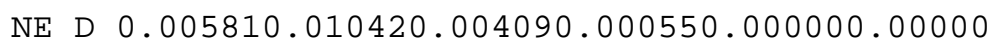

ENE D ०.006330.008360.000960.000000.000000.00000

E D 0.008130 .008770 .000520 .000000 .000000 .00000

ESE D 0.004670 .009690 .000640 .000030 .000000 .00000

SE D $0.004700 .013670 .002870 .000030 .000000 .0000 \odot$

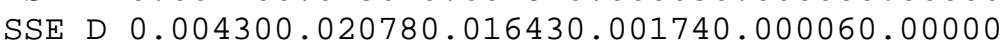

S D 0.004410 .025170 .036280 .009000 .000460 .00003

SSW D 0.005110 .015790 .024880 .009960 .002030 .00015

SW D 0.004410.011000.017150.011700.002380.00015

WSW D 0.003690.008800.012080.011440.002350.00015

W D 0.003340 .008500 .012680 .011350 .003340 .00023

WNW D ๑.003250.008070.012970.009090.003980.00110

NW D 0.003600.008880.012510.005170.001540.00110

NNW D 0.004030.007200.004560.000930.000030.00000

N E 0.000900 .003110 .001480 .000000 .000000 .00000

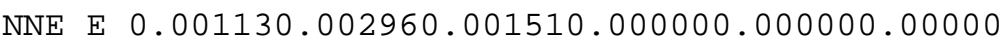

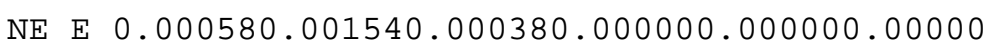

ENE E ०.000520.000840.000090.000000.000000.0000९

E E 0.000580 .000750 .0000000 .000000 .000000 .000000

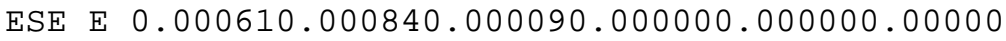

SE E 0.000670 .000960 .000120 .000000 .000000 .00000

SSE E $0.001070 .001860 .000230 .000000 .000000 .0000 \odot$

S E 0.000870 .006410 .001480 .000000 .000000 .00000

SSW E 0.001160.012570.003340.000000.000000.00000

SW E 0.001360.009030.009430.000000.000000.00000

WSW E 0.001190 .003080 .005220 .000000 .000000 .00000

W E ०.000900.002350.002210.000000.000000.00000

WNW E ๑.000840.003450.003190.000000.000000.00000

NW E ०.000870.005780.008010.000000.000000.0000९

NNW E 0.001040 .002700 .001340 .000000 .000000 .00000

N F 0.007400.009200.000440.000000.000000.00000

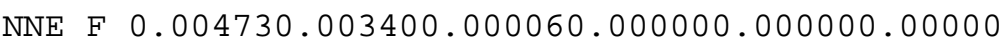

NE F ๑. 002960.000990 .000000 .000000 .000000 .00000

ENE F ०.001770.000460.000000.000000.000000.00000

E F 0.001510 .000260 .000000 .000000 .000000 .00000

ESE F 0.001770.000350.000000.000000.000000.00000

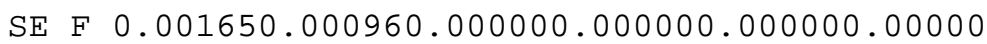

SSE F ๑. 002840.000840 .000000 .000000 .000000 .00000

S F ०.002580.002380.000030.000000.000000.00000

SSW F 0.004990 .005780 .000060 .000000 .000000 .00000

SW F 0.007550 .016430 .001360 .000000 .000000 .00000

WSW F 0.009720 .028740 .007400 .000000 .000000 .00000

W F ०.009960.031870.005080.000000.000000.00000

WNW F ०.009060.024320.003890.000000.000000.00000

NW F 0.009140.027980.002550.000000.000000.00000

NNW F 0.009640.016280.000440.000000.000000.00000 


\section{LANL Radionuclide Air Emissions Report}

\section{Table 7 (continued)}

Table 7b: CAP88 Input Data for 2010 TA-53 Meteorological Tower (100.0\% Data Completeness)

N A 0.000940.000230.000000.000000.000000.00000

NNE A $\odot .001830 .000510 .000000 .000000 .000000 .00000$

NE A 0.003050 .000940 .000000 .000000 .0000000 .00000

ENE A 0.003800 .001460 .000000 .000000 .000000 .00000

E A 0.004140 .002400 .000000 .000000 .000000 .00000

ESE A 0.002450 .001860 .000000 .000000 .000000 .00000

SE A 0.002630 .002170 .000000 .000000 .000000 .00000

SSE A 0.002110 .002000 .000000 .000000 .000000 .00000

S A 0.001110 .001340 .000000 .000000 .000000 .00000

SSW A 0.000800 .000600 .0000000 .000000 .000000 .00000

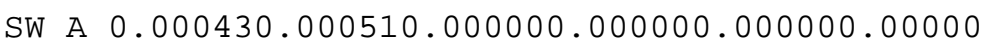

WSW A ०.000370.000340.000000.000000.000000.00000

W A 0.000200 .000370 .000000 .000000 .000000 .00000

WNW A 0.000140 .000260 .000000 .000000 .000000 .00000

NW A 0.000200 .000260 .000000 .000000 .000000 .00000

NNW A 0.000540 .000140 .000000 .000000 .000000 .00000

N B 0.000200 .000290 .000030 .000000 .000000 .00000

NNE B $\odot .000310 .000540 .000030 .000000 .000000 .00000$

NE B 0.001000 .001260 .000000 .000000 .000000 .00000

ENE B 0.001540 .002680 .000030 .000000 .000000 .00000

E B 0.001230 .002940 .000000 .000000 .000000 .00000

ESE B $\odot .000660 .002080 .000000 .000000 .000000 .00000$

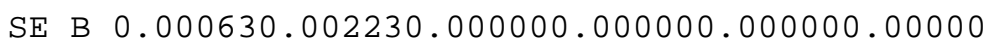

SSE B 0.000540 .002280 .000000 .000000 .000000 .00000

S B 0.000310 .001770 .000030 .000000 .000000 .00000

SSW B 0.000140 .000800 .000030 .000000 .000000 .00000

SW B ०.000200.000510.000000.000000.000000.0000९

WSW B ०.000060.000140.000000.000000.000000.00000

W B 0.000060 .000140 .000000 .000000 .000000 .00000

WNW B 0.000000 .000140 .000000 .000000 .000000 .00000

NW B 0.000170.000140.000060.000000.000000.00000

NNW B 0.000170.000140.000030.000000.000000.00000

N C 0.000430 .000460 .000110 .000030 .000000 .00000

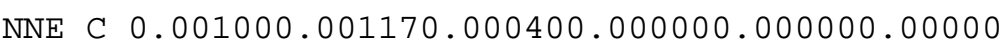

NE C 0.001340 .003620 .000680 .000030 .000000 .00000

ENE C 0.002250 .005740 .000370 .000000 .000000 .00000

E C $0.001910 .006390 .000060 .000000 .000000 .0000 \odot$

ESE C 0.001340 .005050 .000030 .000000 .000000 .00000

SE C $\odot .000830 .004650 .000030 .000000 .000000 .00000$

SSE C 0.000600 .005450 .000290 .000000 .000000 .00000

S C 0.000710 .004990 .000680 .000000 .000000 .00000

SSW C 0.000230.002940.000630.000000.000000.00000

SW C 0.000030 .001660 .000370 .000000 .000000 .00000

WSW C ๑.000090.000940.000770.000030.000000.00000

W C 0.000030 .000860 .000710 .000060 .000000 .00000

WNW C 0.000060 .000860 .000430 .000000 .000000 .00000

NW C 0.000140 .000490 .000060 .000000 .000000 .00000

NNW C 0.000170 .000510 .000140 .000000 .000000 .00000 


\section{Table 7b (continued)}

N D 0.004970 .006510 .006140 .003030 .000060 .00000

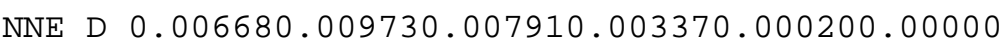

NE D 0.006250.011560.005110.001110.000000.00000

ENE D 0.005710 .010270 .002850 .000140 .000000 .00000

E D 0.005020 .008590 .001680 .000030 .000000 .00000

ESE D ๑.003650.005940.000570.000000.000000.0000९

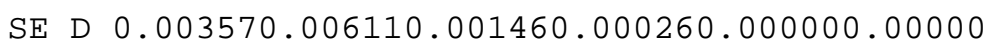

SSE D $\odot .002770 .010760 .008960 .002740 .000910 .00003$

S D 0.003600 .017780 .033740 .016100 .001370 .00037

SSW D 0.002540.014440.037160.025370.004400.00126

SW D 0.001910 .009330 .020920 .014300 .002910 .00023

WSW D ०.001860.006590.014160.011560.002740.00020

W D 0.002250.005110.012900.007530.001680.00009

WNW D 0.002710 .004940 .010760 .005450 .001370 .00003

NW D 0.003140.004080.006110.003030.000830.00046

NNW D ०.003620.004000.004080.002400.000430.00009

N E 0.004000 .007590 .001660 .000000 .000000 .00000

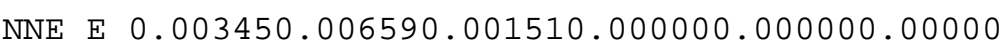

NE E $\odot .002250 .004280 .001370 .000000 .000000 .00000$

ENE E 0.001400 .002110 .000400 .000000 .000000 .00000

E E 0.001400 .001970 .000170 .000000 .000000 .00000

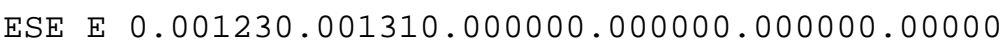

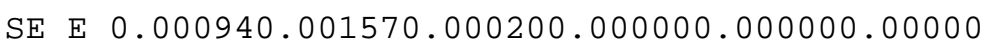

SSE E $\odot .000740 .002400 .000740 .000000 .000000 .00000$

S E 0.001080 .005390 .005110 .000000 .000000 .00000

SSW E 0.001110.010130.020720.000000.000000.00000

SW E 0.001600.018490.017100.000000.000000.00000

WSW E ๑.000970.009330.013440.000000.000000.00000

W E 0.001280 .006590 .008880 .000000 .000000 .00000

WNW E 0.002140 .006710 .006310 .000000 .000000 .00000

NW E ०.002970.004600.002540.000000.000000.0000९

NNW E 0.002850.005370.002510.000000.000000.00000

N F 0.008310 .003140 .000060 .000000 .000000 .00000

NNE F ๑. $008650.002880 .000030 .000000 .000000 .0000 \odot$

NE F 0.007820.002110.000060.000000.000000.00000

ENE F ०.005390.001400.000030.000000.000000.00000

E F 0.004770 .000970 .000000 .000000 .000000 .00000

ESE F 0.004170.000660.000000.000000.000000.00000

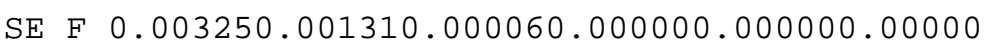

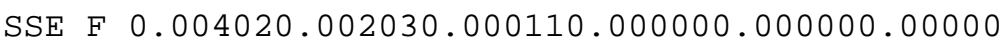

S F ०.004990.004050.000200.000000.000000.00000

SSW F 0.004820.008560.002430.000000.000000.00000

SW F 0.004600.006940.001060.000000.000000.00000

WSW F ०.004650.009020.003800.000000.000000.00000

W F ०.004990.010820.005970.000000.000000.00000

WNW F 0.004510.010330.001510.000000.000000.00000

NW F 0.006710.005170.000830.000000.000000.00000

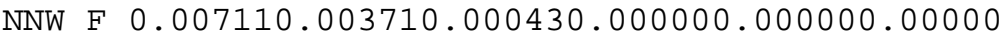




\section{LANL Radionuclide Air Emissions Report}

\section{Table 7 (continued)}

Table 7c: CAP88 Input Data for 2010 TA-54 Meteorological Tower (100.0\% Data Completeness)

N A 0.000800.000460.000030.000000.000000.00000

NNE A $\odot .001030 .000600 .000000 .000000 .000000 .00000$

NE A 0.002400 .001260 .000000 .000000 .000000 .00000

ENE A 0.004250 .002080 .000000 .000000 .000000 .00000

E A 0.005770 .002830 .000000 .000000 .000000 .00000

ESE A 0.005080 .002710 .000000 .000000 .000000 .00000

SE A 0.003740 .002370 .000000 .000000 .000000 .00000

SSE A $\odot .002850 .001800 .000000 .000000 .000000 .00000$

S A 0.001680 .001480 .000000 .000000 .000000 .00000

SSW A 0.000710 .001480 .000000 .000000 .000000 .00000

SW A 0.000800 .000570 .000000 .000000 .000000 .00000

WSW A 0.0000630 .000430 .000000 .000000 .000000 .00000

W A 0.000430 .000230 .000000 .000000 .000000 .00000

WNW A ๑. 000460.000200 .000000 .000000 .000000 .00000

NW A 0.000430 .000310 .000000 .000000 .000000 .00000

NNW A 0.000510 .000200 .000000 .000000 .000000 .00000

N B 0.000110 .000290 .0000000 .000000 .0000000 .00000

NNE B 0.000340 .000630 .000000 .000000 .000000 .00000

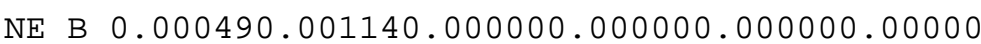

ENE B $\odot .001230 .002570 .000000 .000000 .000000 .00000$

E B 0.001280 .003000 .000000 .000000 .000000 .00000

ESE B 0.000740 .001460 .000000 .000000 .000000 .00000

SE B ०.000260.001200.000000.000000.000000.0000९

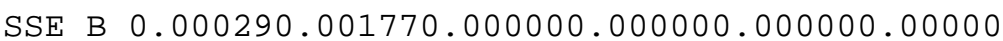

S B 0.000310 .001710 .000000 .000000 .000000 .00000

SSW B 0.000200 .001340 .000060 .000000 .000000 .00000

SW B 0.000060 .000630 .000030 .000000 .000000 .00000

WSW B 0.0000200 .000430 .000060 .000000 .000000 .00000

W B 0.000110 .000310 .000060 .000000 .000000 .00000

WNW B ०.0000090.000290.000090.000000.000000.00000

NW B ०.000060.000090.000030.000000.000000.00000

NNW B 0.000110.000170.000000.000000.000000.00000

N C 0.000170 .000510 .000140 .000000 .000000 .00000

NNE C ०.000660.002030.000200.000000.000000.00000

NE C ०.001060.004570.000230.000000.000000.0000९

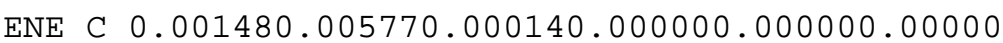

E C 0.001140 .004280 .000090 .000000 .000000 .00000

ESE C $0.000800 .002510 .000090 .000000 .000000 .0000 \odot$

SE C $0.000660 .002230 .000090 .000000 .0000 \odot \odot .000 \odot \odot$

SSE C ๑. 000540.003400 .000260 .000000 .000000 .00000

S C 0.000340 .005370 .000860 .000000 .000000 .00000

SSW C $\odot .000230 .004510 .000770 .000000 .000000 .00000$

SW C 0.000260 .001200 .000860 .000000 .000000 .00000

WSW C ०.000030.000910.000830.0000000.000000.00000

W C 0.000140 .001200 .001510 .000060 .000000 .00000

WNW C ๑.000200.000660.001170.000060.000000.0000९

NW C ๑. $000230.000490 .000400 .000030 .000000 .0000 \odot$

NNW C ०.000200.000340.000030.000000.000000.00000 


\section{Table 7c (continued)}

N D 0.005450 .005940 .002800 .001370 .000140 .00000

NNE D ๑.005250.012700.011160.004250.000110.00003

NE D 0.006140.015930.009110.001200.000060.00000

ENE D ०.004000.008160.002000.000140.000000.0000९

E D 0.002830 .004080 .000430 .000030 .000000 .00000

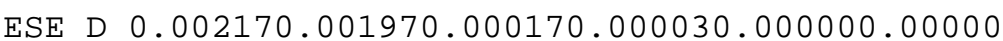

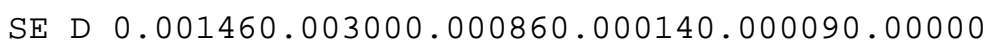

SSE D $\odot .001430 .004800 .003830 .005310 .001570 .00031$

S D 0.001880 .009050 .021240 .019100 .004910 .00069

SSW D 0.002310.013760.044450.036910.008340.00257

SW D 0.002770 .011080 .020300 .015790 .004050 .00077

WSW D 0.002140 .006970 .007910 .006110 .001340 .00000

W D 0.003910.005990.007850.004140.000310.00003

WNW D 0.004220 .005340 .007740 .002830 .000230 .00000

NW D 0.005050.007510.004540.001430.000260.00003

NNW D ०.005220.004650.002650.001200.000110.00000

N E 0.003570 .004940 .001770 .000000 .000000 .00000

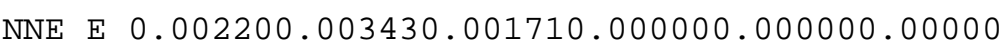

NE E 0.001600 .002630 .000740 .000000 .000000 .00000

ENE E $\odot .001080 .001570 .000230 .000000 .000000 .00000$

E E 0.000940 .000660 .000090 .000000 .000000 .00000

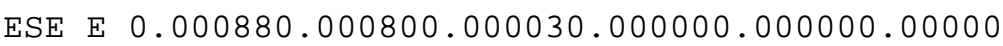

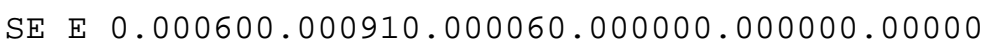

SSE E ๑.000430.001770.000570.000000.000000.0000९

S E 0.000710 .003510 .003000 .000000 .000000 .00000

SSW E 0.001280.006770.013300.000000.000000.00000

SW E 0.001460.010080.015040.000000.000000.00000

WSW E 0.001940 .007140 .003400 .000000 .000000 .00000

W E 0.002540 .011760 .002740 .000000 .000000 .00000

WNW E 0.002910 .011480 .004080 .000000 .000000 .00000

NW E 0.004800 .010700 .002030 .000000 .000000 .00000

NNW E ๑.004370.005970.000880.000000.000000.00000

N F 0.007880 .012360 .000770 .000000 .000000 .00000

NNE F ๑. $005370.006250 .000260 .000000 .000000 .0000 \odot$

NE F 0.003400.002480.000060.000000.000000.00000

ENE F ०.001860.001140.000000.000000.000000.00000

E F 0.000660 .000460 .000000 .000000 .000000 .00000

ESE F ०.000880.000000.000000.000000.000000.00000

SE F ०.000570.000340.000000.000000.000000.00000

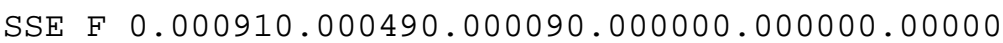

S F ०.001230.001710.000290.000000.000000.00000

SSW F 0.002450.004450.001230.000000.000000.00000

SW F 0.003200 .016300 .005620 .000000 .000000 .00000

WSW F ०.004220.019070.006710.000000.000000.00000

W F ०.005970.020780.003970.000000.000000.00000

WNW F 0.010280.017130.000370.000000.000000.00000

NW F ०.012960.038360.001230.000000.000000.0000९

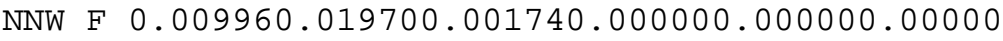


This report has been reproduced directly from the best available copy. It is available electronically on the Web (http://www.doe.gov/bridge).

Copies are available for sale to U.S. Department of Energy employees and contractors from:

Office of Scientific and Technical Information

P.O. Box 62

Oak Ridge, TN 37831

(865) 576-8401

Copies are available for sale to the public from: National Technical Information Service

U.S. Department of Commerce

5285 Port Royal Road

Springfield, VA 22161

(800) 553-6847 
- Los Alamos NATIONAL LABORATORY 